\title{
SD
}

U. S. DEPARTMENT OF AGRICULTURE, FOREST SERVICE. HENRY S. GRAVES, Forester.

\section{THE NATIONAL FOREST' MANUAL.}

REGULATIONS OF THE SECRETARY OF AGRICULTURE AND INSTRUCTIONS TO FOREST OFFICERS RELATING TO AND GOVERNING THE GRAZING OF LIVE STOCK UPON NATIONAL FOREST LANDS.

ISSUED BY THE

SECRETARY OF AGRICULTIRE

TO TAKE EFFECT MAY 1, 1911

\section{GRAZING.}

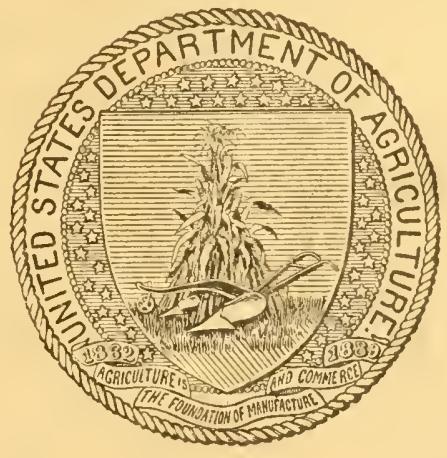

TASHINGTON :

GOYFRNIENT PRINTINA OFFICE. 


$$
\%
$$





) 


\section{U. S. DE.PARTMENT OF AGRICULTURE,}

FOREST SERVICE.

HENRY S, GRAVES, Forester.

\section{'THE NATIONAL FOREST' MANUAL.}

REGULATIONS OF THE SECRETARY OF

AGRICULTURE AND INSTRUCTIONS TO FOREST OFFICERS

RELATING TO AND GOVERNING THE GRAZING OF

LIVE STOCK UPON NATIUNAL FOREST LANDS.

ISSUED BY TIIE

SECRETARY OF AGRICULTURE

TO TAKE EFFECT

$\mathrm{MAY} 1,1911$

\section{GRAZING.}

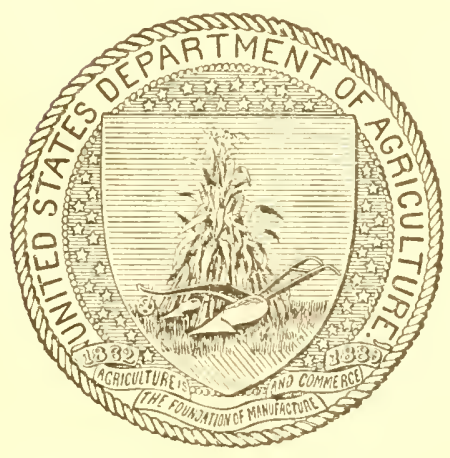

WASHINGTON :

GOVERNMENT PRINTING OFFICE. 
The Secretary * * * may make such rules and regulations * * * as will insure the objects of said reserrations, namely, to regulate their occupancy and use and to preserve the forests thereon from destruction; and any riolation of this act or such rules and regulations shall be punished (by $\$ 500$ fine or 12 months' imprisonment, or both) as is provided for in the act of June 4, 18s8, amending section 5388 of the Revised Statutes of the United States. (Act of June 4, $1 \$ 97,30$ Stat., 11.) 


\section{CONTENTS.}

Page.

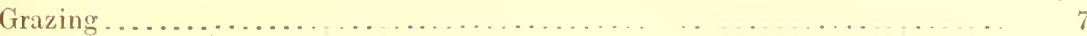

Grazing Regulations:

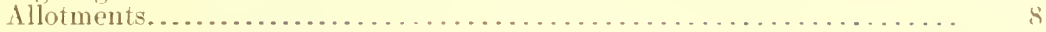

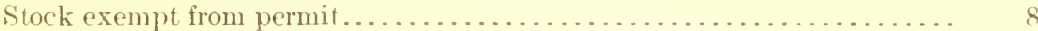

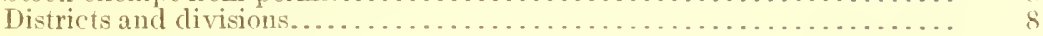

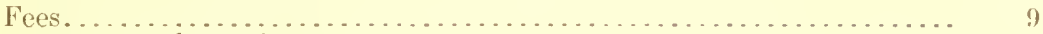

Payments and permits. . . . . . . . . . . . . . . . . . . . . . .

Refunds. . . . . . . . . . . . . . . . . . . . . . . . . . . . . .

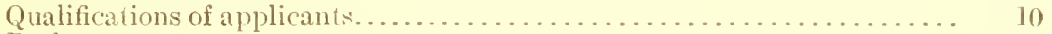

Preferences.......................................... 10

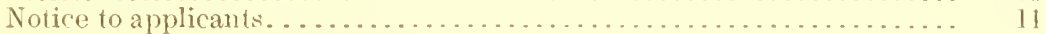

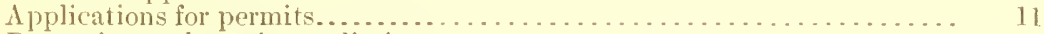

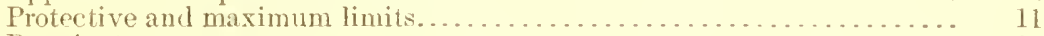

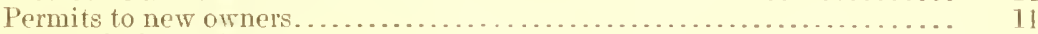

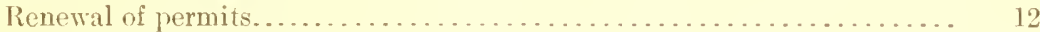

Settlement of controversies. . . . . . . . . . . . . . . . . . . . . . . . 12

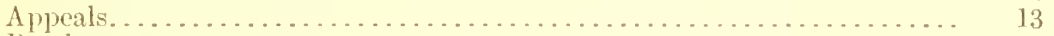

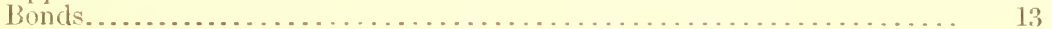

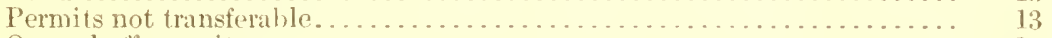

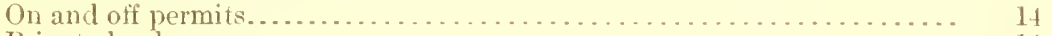

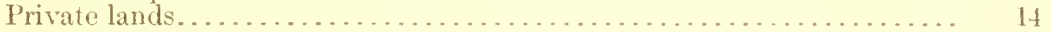

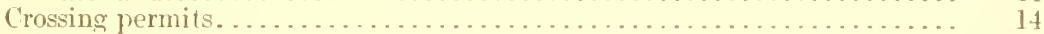

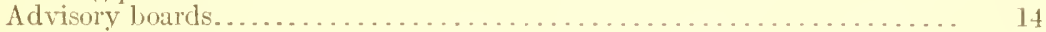

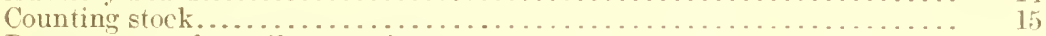

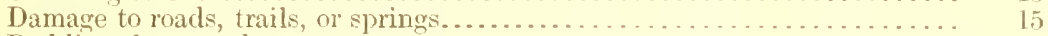

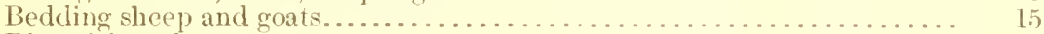

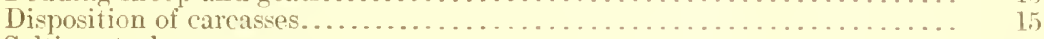

Salting stock . . . . . . . . . . . . . . . . . . . . . . . . . . .

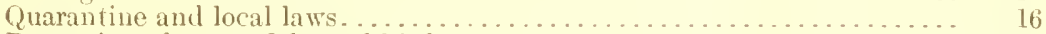

Protection of game, fish, and birds. . . . . . . . . . . . . . . . .

Instructions to Forest Officers:
Allotments.

Stock exempt from permit . . . . . . . . . . . . . . . . . . . . .

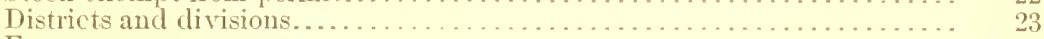

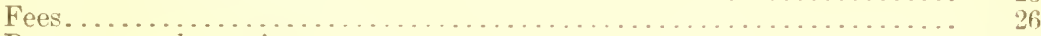

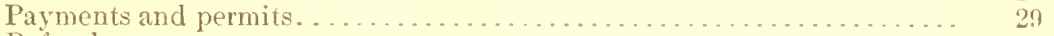

Refunds. . . . . . . . . . . . . . . . . . . .

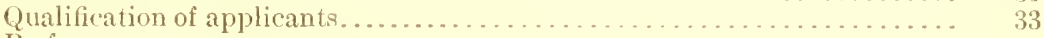

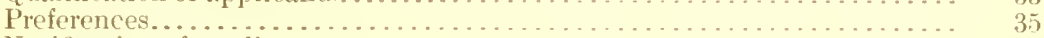

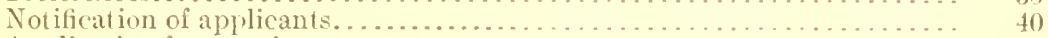

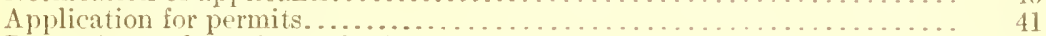

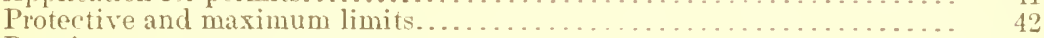

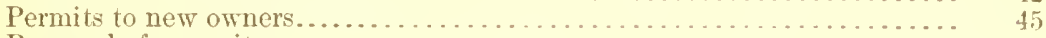

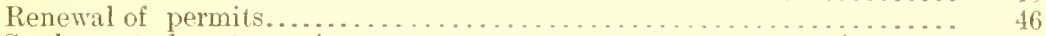

Settlement of controversies. . . . . . . . . . . . . . . . . . . . . . 50

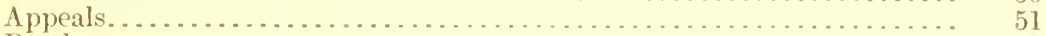

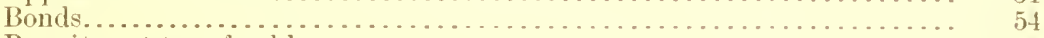

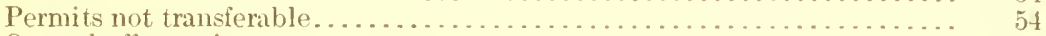

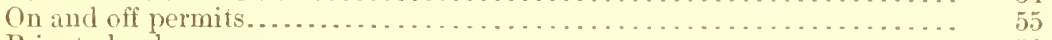

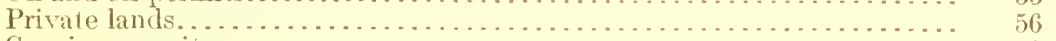

Crossing permits. . . . . . . . . . . . . . . . . . . . . . . . . . . .

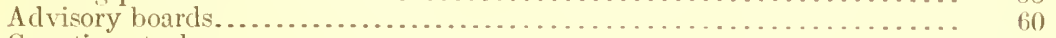

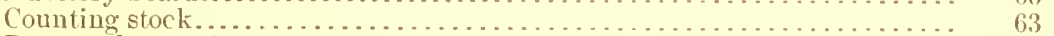

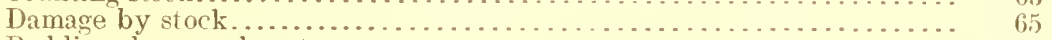

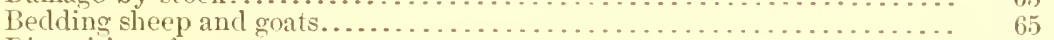

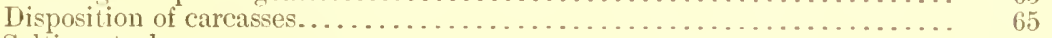

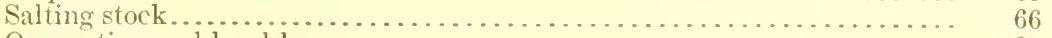

Quarantine and local laws. . . . . . . . . . . . . . . . . . . . . . . . . . . 67

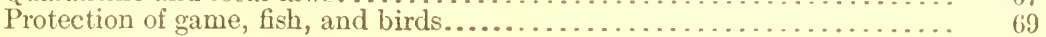




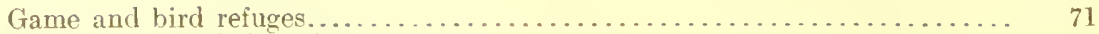

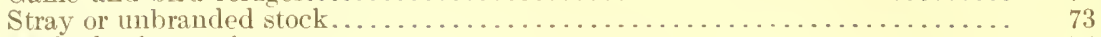

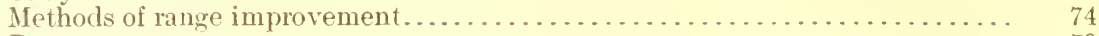

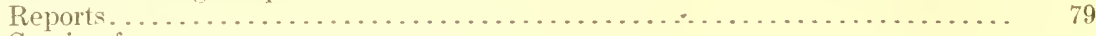

Grazing forms:

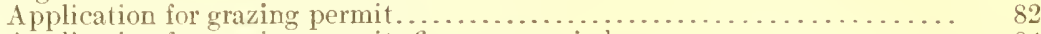

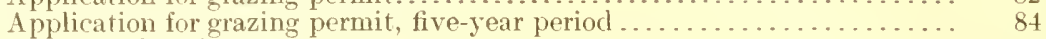

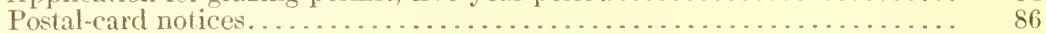

Notice to grazing applicant and letter of transmittal.............. 87

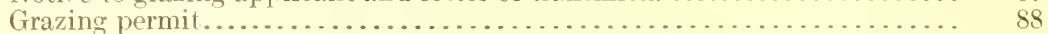

Application for permit on account of private land .............. 89

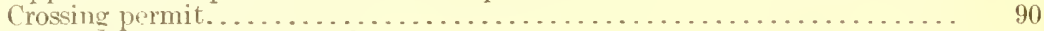

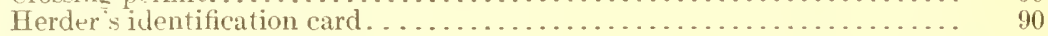

Waiver of grazing privilege . . . . . . . . . . . . . . . . . . . . . 91

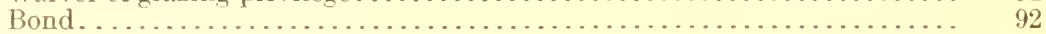

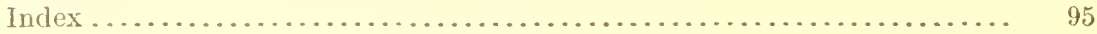


United States Departalent of Agriclltere.

\section{Office of the Secretary.}

\section{WASIINGTON, D. C.}

$\mathrm{By}$ virtue of the authority vasted in the Secretary of Agriculture by the act of Congress of February 1,1905 (33 Stat., 628), amendatory of the act of Congress of June 4, 1897 (30 Stat., 11), I, James Wilson, Secretary of Agriculture, do make and publish the following regulations for grazing upon National Forest lands, the same to supersede all previous regulations for like purposes and to be in force and effect from the first day of May, 1911, and to constitute a part of the Use Book.

In testimony whereof I have hereunto set my hand and oflicial seal, at Washington, D. C., this 1Sth day of March, 1911.

JAMES WiLson,

Secretary of Agriculture. 



\section{THE NATIONAL FOREST MANUAL.}

\section{GRAZING.}

The Secretary of Agrieulture has anthority to permit, regulate, or prohibit grazing in the National Forests. "Under his direction the Forest Service will allow the uise of the forage crop as fully as the proper care and protection of the forests and the water supply permit. The cattle and sheep which are grazed in the National Forests bear an important relation to the supply of beef and mutton in this country, and every effort will be made by Forest officers to promote the fullest possible use of the grazing resources. The utilization of forage grasses and plants also reduces the fire danger and helps to protect the Forests. In new National Forests, where the live-stoek industry is of special importance, full grazing privileges will be given at first, and if reduction in number is afterwards found necessary stockmen will be given ample opportunity to adjust their business to the new conditions. Every effort will be made to clistribute the stock satisfactorily on the range, in order to secure greater liarmony among the users of the Forests, to reduce the waste of forage by tramping in unnecessary morement of stock, and to obtain a more permanent, juclicious, and profitable use of the range.

The leading objects of the grazing regulations are:

The protection and conservative use of all National Forest land adapted for grazing.

The permanent good of the live-stock industry through proper care and improvement of the grazing lands.

The protection of the settler and home builder against unfair competition in the use of the range.

It is expected that the stock owners will earnestly cooperate in carrying out the regulations.

Permits will he issued to graze a certain number of live stock in each National Forest, or part thereof, so long as no damage is done br such stock. A reduction will be made from the number of stock grazed during the previous season if, owing to the number grazed or the method of landling the stock, damage is being done to the Forest, and in extreme cases all stock will be excluded.

Cattle and horses will usually be allowed to graze in all National Forests. Sheep and goats will be allowed to graze in National Forests or in parts thereof where the conditions warrant, but will be restrieted to the areas and grazing periods fixed by the Forest Service.

Permits will usually be granted for one year, but where all controversies have been settled and proper numbers of stock are allowed, the Secretary of Agriculture will authorize the approval of applications for periods of not more than five rears, with the understanding that all permits are terminable at any time and that the renewal of permits will be within his discretion. 


\section{GRAZING REGULATIONS.}

\section{ALLOTMENTS.}

Reg. G-1. The Secretary of Agriculture will prescribe each year the number of stock to be allowed in each National Forest, and will authorize the approval of applications for permits during periods of one or more years, but revocable at any time within his discretion. 'The yearlong grazing fee to be charced for' each class of stock will be determined by the Forester in accordance with Reg. G-4. Seasons less than yearlong will be established by the District Forester, who will determine the fees to be charged for each short season in accordance with the cstablished schedule and the provisions of Reg. G-4. When notified of the establishment of crazing allowances and yearlong rates for any National Forest, the District Forester will establish and fix the rates for all grazing periods less than yearlong and will transmit instructions to the Supervisor, who will issue grazing permits in accordance therewith. Fifteen days may be added to the grazing period, in the discretion of the Supervisor, without charge.

\section{STOCK EXEMPT FROM PERMIT.}

Reg. G-2. All persons must secure permits before grazing any stock in a National Forest, except for the few head in actual use by prospectors, campers, and travelers, or saddle, pack, and work animals actually used in connection with permitted operations on the National Forests, and milch or work animals not exceeding a total of 10 head owned and in use by bona fide settlers residing in or near a National Forest. which require no permit.

\section{DISTRICTS AND DIVISIONS.}

Reg. G-3. The grazing of sheep and goats upon any portion of a Forest must not be allowed until authorized by the Forester. This authorization secured, the kind of stock to be grazed in each district open to grazing on the Forests will be deternined by the District Forester. Under his general instructions, National Forests in which grazing is allowed will be divicled into districts by the Supervisor, who will provide for the distribution of stock among the districts, and make such range divisions among applicants for grazing permits as appear most equitable and for the best interests of the National Forest and its users. When required for the protection of camping places, lakes and streams, roads and trails, ete., or of areas which are to be reforested, the Supervisor may exclude stock from specified areas for such period of time as is necessart. Stock will he excluded from areas where they will destroy young growth or will prevent reproduction. 
FEES.

Reg. G-4. A reasonable fee will be charged for grazing all kinds of live stock on National Forests, except as otherwise provided in these Regulations. The rates will be based upon the yearlong rate for cattle which will be from 35 to 60 cents per head, depending upon the advantages and the locality of the Forest.

The yearlong rates for horses will be from 25 to 40 pel cent more, and the yearlong rates for swine from 25 to 40 per cent less than the rate for cattle. On Forests where the quality of range and advantages for grazing cattle and sheep or goats are equal, the ycarlong rate for sheep and goats will be 30 per cent of the yearlong rate for cattle, but where the above-mentioned conditions warrant it, this percentage may be departed from and the yearlong rates for sheep and goats fixed within the following limits: From 10 to 12 cents on Forests where the rate for cattle is 35 cents; from 12 to 14 cents on Forests where the rate for cattle is 40 cents; from 12 to 15 cents on Forests where the rate for cattle is 45 cents; from 14 to 16 cents on Forests where the rate for cattle is 50 cents; from 15 to 18 cents on Forests where the rate for cattle is 60 cents.

The rates for all kinds of stock for periods shorter than yearlong will be based ujon a charge of one-ninth of the annual rate per month for periods of less than four months or periorls beginning between July 15 and October 15, or of one-tenth of the annual rate per month for periods of four months or over begimning between October 16 and July 14, provided that the rates on sheep, goats, and swine shall not be divided into fractional amounts of less than one-fourth of 1 cent, and the rates on cattle and horses shall not be divided into fractional amounts of less than 1 cent; and provided that the minimum rate for any short period shall not be less than 20 cents per head on cattle, 25 cents per head on horses, 12 cents per head on swine, or 5 cents per head on sheep or goats. An extra charge of 2 cents per head will be made for sheep or goats which are allowed to enter the National Forests for the pulpose of lambing or kidding. No charge will be made for animals under 6 months of age at the time of entering the Forest, which are the natural increase of stock upon which fees are paid or for those born during the season for which the permit is allowed: Provided, however. That the grazing fees in furce at the date of these Regulations shall continue in eflect for all permits issued prior to and including December 31, 1911.

\section{PAYMENTS AND PERMITS.}

Reg. G-5. All grazing fees are payable in advance. When an applicant for a grazing permit is notified by the Supervisor that his application has been approved, he will remit the amount due for grazing fees to the District United States Depository, and upon receipt of notice by the Supervisor that payment has been made, a permit will be issued allowing the stock to enter the Forest and remain during the period specified.

Persons who fail to pay the grazing fee before the beginning of the grazing period mist notify the Supervisor and give satisfactory reasons, or within the discretion of the Supervisor may be denied a grazing permit the following season. 


\section{REFUNDS.}

Reg. G-6. Grazing fees will not be refunded for nonuse of the permit, except when, in the opinion of the District Forester, the applicant is prevented from using the range by circumstances over which he has no control, or his range is trespassed upon, or renewal of permit is allowed to a purchaser of the stock.

\section{QUALIFICATIONS OF APPIICANTS.}

Reg. G-7. Grazing permits will be issued only to persons entitled to share in the use of the range within National Forests by virtue of prior use and occupancy of National Forest lands for grazing purposes; or by local residence, ownership of improved ranch property withim or near the Forest, and dependence upon the range; or by the acruisition of stock grazed upon National Forest lands under permit and of improved ranch property used in connection with the stock, uncler circumstances which warant an entire or partial renewal of the permit issued to the former owner, except when there is surplus range, in which rase temporary permits may be issued to owners of transient stock.

Nonuse of a range during one rear, except as authorized by the District Forester, will be sufficient grounds for the denial of grazing privileges.

\section{PREFERENCES.}

Reg. G-8. Citizens of the United States will be given preference in the use of the National Forests, but persons who are not citizens may be allowed grazing permits provided they are bona fide residents and owners of improved ranch property either within or adjacent to a National Forest.

Regular occupants of the range who own and reside upon improved ranch property in or near National Forests will be given first consideration, but will be limited to a number which will not exchde regular occupants who reside or whose stock are wintered at a greater distance from the National Forests. With this provision applicants for grazing permits will be given preference in the following order:

Class 1: Persons owning and residing upon improved ranch property within or near a National Forest who are dependent upon the National Forest for range and who do not own more than the established protective limit number of stock.

Class B: Regular users of National Forest range who own numbers of stock in excess of the established protective limits, or who do not own improved ranch property within or near a National Forest.

Class (C: Persons who are not regular users of National Forest range and who do not own improved ranch property within or near a National Forest. Class C applicants will not be granted permits upon Forests which are fully occupied by permittees of classes $\mathrm{A}$ and $\mathrm{B}$.

Persons who have not regularly used the range within newly created National Forests during preceding years will not be allowed to place stock upon it for the purpose of establishing a grazing priority, unless they are bona ficle settlers living either within or adjacent to the National Forest, who are entitled to share in the use of the range as class $A$ applicants. 
NOTICE TO APPLICANTS.

Reg. G-9. When notice of the grazing allowance, periods, and rates for each year has been received by the Supervisor he will give public notice of a clate on or before which all applications for grazing must be presented to him. Permits may be refused to persons who do not file their applications within the required time unless satisfactory reasons are given.

\section{APPLICATION FOR PERMITS.}

Reg. G-10. Applications for grazing permits must be submitted on blank forms which will be furnished by the Supervisor and the information necessary to complete the application must be furnished in detail. The number of stork must not be greater than the number the applicant actually owns or intends to purchase or less than the number he intends to graze upon the Forest. Speculation in the use of grazing permits will not be allowed, and permits will be refused or canceled for intentional false statement of the number of stock owned.

For all purposes of permanent allotment each member or stockholder of a firm or corporation will be considered as holeling a permit to graze the full number of stock covered by any and all grazing permits issued to such firm or corporation. 'The individual permit of a person who anquires an interest in the permit of any firm or corporation will be subject to reduction in its renewal when the combined number of stock covered by all permits in whirh the person is interested exceeds the maximum limit.

\section{PROTECTIVE AND MIAXIMUM LIMITS.}

Reg. G-11. When necessary to secure an equitable distribution of grazing privileges the District Forester will establish protective limits covering the number of stock for which the permits of small owners will be exempt from reduction in their renewal. Permits for numbers of stoek in excess of the protective limits will be subject to necessary slicling scale or other retuctions and will not be subject to increase in number except through purchase of stock and ranches of other permitters. (See Reg. G-13.)

When necessary to prevent monopoly of the range the District Forester will establish maximum limits in the number of stock for which a permit will be issued to any one person, firm, or eorporation. Permits for numbers of stock in excess of the maximum linits will be issued only to persons who, eluring the preceding year, held permits to graze numbers of stock equal to or greater than that for which application is made. The District Forester may suspend the maximum limit in speeial eases.

\section{PERMITS TO NEW OWNERS.}

Reg. G-1\%. Grazing applications, other than for renewal of permit, will not be approred if the average number of stock per permit upon the Forest is more than 20 per eent below the established protective limit number, or if the approval of such applieations require a reduction of more than 20 per cent upon any permit of the preceding year. If a Forest is fully stocked the total number of stock to be 
distributed among new applicants and permittees below the protective limit during one year must not exceed 3 per cent of the total number authorized for the rear, and no new permit will be issued for more than one-lialf of the protective limit number; or, if the average number of stock per permit is less than the established protective limit, no new permit will be issued for more than one-fourth of the protective limit number, nor will such permit be issued except for stock which will be fed during the winter from the products of the permittee's ranch.

Upon fully stocked Forests, applications other than for renewal of permit will not be considered unless filed with the Supervisor six months before the beginning of the grazing season.

Persons who have sold their stock grazed under permit and signed a waiver to their preference will not be recognized as new applieants for a period of three years from the date of the waiver, except as purchasers of permitted stock.

\section{RENEWAL OF PERMITS.}

Reg. G-13. Grazing permits will be renewed only when the grazing of the class of stock involved is authorized by the Secretary of Agriculture. Permits for numbers of stock in excess of the established protective limits will be subject to reduction in their renewal, and no division or sale of stock and ranches will exempt such permits from reduction. A permit may be divided in its renewal because of division of stock and ranches between two or more owners or purchasers, but not more than one permit will be issucd for less than the proteetive limit number of stock because of such division.

A renewal of permit may be allowed the purchaser of stock grazed under permit and the ranches used in connection therewith, provided that the permittee from whom the stock is purchased has used the range during three or more successive years and the purchaser has secured a waiver from the permittee of all preference in renewal of the permit. The mere purchase of stock grazed under permit will not entitle the purchase to share in the grazing privilege, but if he is the owner of improved ranch property which is commensurate, and used in connection, with the stock a renewal of permit may be allowed for not to exceed 80 per cent of the number of stock purchased, and provicled that a full renewal will be allowed if the purchaser is a resident ranch owner who does not own a total of more than the protective limit number of stock. When all stock grazed under permit and all ranch property used in connection thereof by a permittee is purchased a full renewal of permit may be allowed subject to the maximum limit restriction and to necessary reductions applicable to other permits of the same class.

\section{SETTLEIENT OF CONTROVERSIES.}

Reg. G-14. Whenerer there is a dispute between grazing applicants for the same area the Supervisor will notify them to appear before him at a stated time and place, to make a statement of their claims. After all eridence has been presented the Supervisor will decide who shall be granted permits, and will forthwith notify each party to the dispute of his decision and his reasons therefor, which will be final unless written notice of appeal to the District 
Forester is given within 10 days thereafter. Upon filing such notice 20 days will be allowed for preparation of the case for presentation to the District Forester.

\section{APPEALS.}

Reg. G-15. The disapproval of an application for grazing privileges, the denial of an increase or the requirement of a reduction in the number of stock covered by a permit in its renewal, or the disapproval of a request for a certain range allotment by the Supervisor shall be considered final unless written request for a reconsideration of the case is filed with the Supervisor within 10 days from the date of the receipt of his decision. "The decision of the Supervisor after a reconsideration of the case slall be considered final unless written notice of appeal to the District Forester is filed with the Supervisor within 10 lays from the receipt of his decision. 'The decision of the District Forester, unter this or the foregoing regulation, shall be considered final unless writen notice of appeal to the Forester is filed with the District Forester within 10 days from the receipt of his decision. Appeal may also be taken to the Secretary of Agriculture from adverse decisions of the Forester and must be presented to the Secretary of Agriculture within 30 days from notice of the dreision of the Forester. Appeal under this or the foregoing regulation to the District Forester, the Forester, or the Secretary of Igriculture will avail only when it is shown by the evidence submitted that the decision is not warranted by the facts or is contrary to the grazing regulations or the instructions covering the allotment of grazing privileges.

\section{BONDS.}

Reg. G-16. Whenever it is necessary for the protection of a National Forest, or of the interests dependent upon it, the Supervisor may require the owners of transient stock, or nonresidents of the State or Territory in which the Nationa! Forest is located, or persons who have persistently violated the regulations of the Secretary of Agriculture to give good and sufficient bond to insure payment for all damage sustained by the Government through violation of the regulations or the terms of the permit.

\section{PERMITS NOT TRANSFERABLE.}

Reg. G-17. Permits will be granted only for the exclusive use and benefit of the owners of the stock, and will be forfeited if sold or transferred in any manner or for any consideration. If stock grazed under permit is sold during the term of the permit the original permit must be surrendered to the Supervisor, who upon receipt of evidence that the sale is bona fide will cancel the original permit and will issue, free of charge, an amended permit to the original permittee for the number of stock retained and a permit to the purchaser for the number of stock purchased, which will allow the grazing of such stock upon the National Forest during the remainder of the permit period. Action upon the application of the purehaser in subsequent permit allotments will be in accordance with the regulations and instructions governing the renewal of permits to purchasers. 


\section{ON AND OFF PERIITS.}

Reg. G-18. Persons owning stock which regularly graze on ranges only partially included within a National Forest, or upon range which includes private land of unknown ownership, may be granted permits for such portion of their stock as the circumstances appear to justify, but may be required so to herd or handle their stock as to prevent trespassing by that portion for which a permit is not granted.

\section{PRIVATE LANDS.}

Reg. G-19. Persons who own, or who have leased from the owners, unfenced land within any National Forest which they desire to use for grazing purposes without being required to keep their stock upon the land, upon waiving the right to the exclusive use of the private land and allowing it to remain open to other stock grazed upon National Forest land under permit, will be allowed, free of charge, to graze the number of stock upon the National Forest which the private lands will support.

The application must be accompanied by a personal certificate of title showing the description and ownership of the land, and, if leased from an owner, a copy of the lease, and must state the number and kind of stock permit is desired for, the range which it is desired to occupy, and the period during which the stock will remain upon the Forest. Permits will be subject to the same restrictions regarding the use of the range as permits issued under other regulations.

\section{CROSSING PERMITS.}

Reg. G-20. Persons wishing to drire stock across any portion of a National Forest to reach either prirate or pubtic lands, except when the stock will be driven along a public highway or will not be grazed upon National Forest lands, must make application to the Supervisor or other Forest officer for a permit to graze the stock en route and must have a permit from the Supervisor, or such other Forest officer as he may designate, before entering the National Forest. 'The application must state the number of stock to be driven, the date of starting, and period required for passage. Grazing must be confined to the limits and along the route designated by the Forest officers, and will only be allowed for the period necessary for stock to cross the National Forest.

\section{ADVISORY BOARDS.}

Reg. G-21. Whenever any live stock association whose membership includes a majority of the owners of any class of live stock using a National Forest or portion thereof shall select a committee, an agreement on the part of which shall be binding upon the association, such committee, upon application to the District Forester, may be recognized as an advisory board for the association, and shall then be entitled to receive notice of proposed action and have an opportunity to be heard by the local Forest officer in reference to increase or decrease in the number of stock to be allowed for any year, the division of the range between different classes of stock or their owners, or the adoption of special rules to meet local conditions. 
Whenever a State lirestock association appoints an advisory board it may be recosnized by the District Forester and consulted with in regard to matters which affect the general administration of the National Forests within the entire State.

Whenever a National livestock association, representing the owners of any kind of stock, appoints an advisory board or eommittee representing the users of the National Forests in all of the different States, it will be recognized by the Secretiry of Igriculture and the Forester and consulted with annually regarding matters which concern the general welfare of the stockmen using the National Forest ranges.

\section{COUNTING STOCK.}

Reg. G-22. When an owner who has a permit is ready to drive in his stock he must notify the nearest Forest officer, br mail or otherwise, stating the number to be driven in. If called upon to do so, he must provicle for having his stock counterl before entering a National Forest, or at any time afterwards when the number of stock appears to be greater than the number covered hy permit. Whenever any stock is removed before the expiration of the permit, it can be replaced by other stock to fill out the number covered by permit if the Forest officer is notified of such action at once.

\section{DAMAGE TO ROADS, TRAILS, OR SPRINGS.}

Reg. G-23. Each person or group of persons granted grazing permits must repair all damage to roads or trails eaused by the presence of their stock in any portion of a National Forest, and build any new roads or trails found necessary for the proper handling of their stock. They must also fence any spring or seep which is being damaged by the tramping of their stock, ancl, if required by the Supervisor, must pipe the water into troughs for watering stock. Such troughs must be open for public use.

\section{BEDDING SHEEP AND GOATS.}

Reg. G-24. Sheep and goats must not be bedded more than six nights in succession in the same place, exeept when berling bands of ewes during lambing season; and must not be bedderl within 300 yards of any rumning stream or living spring, except in rare cases where this restriction is clearly impracticable.

\section{DISPOSITION OF CARCASSES.}

Reg. G-25. The carcasses of all animals whicli die on the National Forest from contagious or infectious diseases must be bumed and the earcasses of all animals which die in the close vicinity of water must be removed immediately, and buried or burned.

\section{SALTING STOCK.}

Reg. G-26. Whenever the Forest officers require it, all stock grazed under permit must be salted regularly at such places and in such manner as they may designate. 


\section{QUARANTINE AND LOCAL LAWS.}

Reg. G-2\%. All stock which is grazed under permit in, or allowed to cross, any National Forest will be required to conform to the quarantine regulations of the Secretary of Agriculture, and all live stock laws of the State or 'Territory in which the National Forest is located. Forest officers whll cooperate with State or Territorial officials, so far as they can without undue interference with their regular Forest work, to enforce local laws for the protection of stock, and will promptly inform the State officials of all riolations discovered.

\section{PROTECTION OF GAME, FISH, AND BIRDS.}

Reg. G-28. All Forest officers will cooperate with State or Territorial officials, so far as they can without undue interference with their regular Forest work, to enforce local laws for the protection of birds, fish, and game. When properly authorized to do so they will act without additional pay as deputy game wardens with full power to enforce local laws, but may not accept any fees or rewards or parts of fines on account of the enforcement of State game laws. Forest officers and employees may, however, accept any bounties voluntarily offered by any State or county or any association or individual for the destruction of predatory wild animals. 


\title{
INSTRUCTIONS TO IOREST OFFICERS.
}

\author{
U. S. Departient of Agriculture, \\ Forest Service, \\ Washington, D. C., Murch 18,1911.
}

The following procedure and instructions are hereby established and issued to take effect May 1, 1911, governing the enforcement of the regulations of the Seeretary of Agriculture relating to the grazing of live stock in the National Forests.

Approved:

H. S. Graves, Forester.

JAMES Wrilson, Secretary.

\section{ALLOTMENTS. (Reg. G-1.)}

The Secretary of Agriculture prescribes the number and etass of stock Authority. to be allowed upon each Forest and the schedule of grazing fees. The yearlong fees for each Forest within the limits prescribed by the Secretary of Agriculture are determined by the Forester to secure uniformity between different administrative districts. The short grazing periods and the accompanying feesare determined within the limits prescribed by the Secretary of Agriculture by the Distriet Forester to secure uniformity between different Forests in the same Distriet.

When an applieation is received for grazing a kind of stock whieh Applications, for has not been provided for by the Secretary of Agrian una ut hor ored eulture, a full report with recommendations will be ciass of stock. made to the District Forester and his instructions received before disapproval of the application.

All instructions in reference to the issuance of permits for any Allowance letters one year will remain in foree during subsequent effoctlve until ro- year' unless revoked or superseded by other roked. instructions.

All stock upon which fees are paid are counted against the stock chargeabie number of stoek allowed upon a Forest by the against allotment. Secretary of Agrieulture.

Stock grazed free of charge under Reg. G-2 or under Reg. G-19, stock grazed under free permits issued on account Stock not charge-
able against allot- of the sale and transfer of stock, Reg. G-17, or under ment. $\quad$ free erossing permits, Reg. G-20, and stock under 6 months old at time of entry, which is the natural increase of stock covered by permit, are not ehargeable agaimst the allotment.

The total number of stock allowed under pait permit upon the Forest at any one time during the year must not Allowance must exceed the number authorized by the Seeretary of
not be exceeded. Agrieulture under Reg. G-1.

When the issuance of permits for different short periods causes the total number of stock covered by all permits issued during the year 
to exceed the number authorized, an explanatory note should be added in making the anmual report at the end of the fiscal year.

Where Forests are created or additions made after the begimning Allowances on new of the grazing season, the Seeretary of Agriculture, Forests or addi- except under unusual circumstances, will authorize tions. the grazing use of the area free of charge and without permit until the beginning of the next grazing year by all persons who have regularly used the range during preceding years for any class of stock.

During the first season a Forest or new addition is under administration, the Supervisor should make an investigation Stock census on to ascertain the names of the stockmen using the
new additions. new additions. range and the number of each kind of stock they are grazing upon it, and any other information necessary for him to make proper recommendations in his annual Forest plan in reference to grazing allowances, periods, rates, and the division of the range into grazing districts. This may be accomplished by sending to the rangers a list of all questions upon which the Supervisor desires information.

If he considers it necessary for the proper control of grazing upon newly created Forests or upon new additions to the Forests, the Supervisor may issue herder's identification eards to persons who show priority in the use of the range, retaining a record of each card.

Since the Secretary of Agriculture's authorization is based upon the Supervisor's estimate of the grazing capacity of

Grazing estimate. his Forest, the estimate should be carefully prepared. The first step should be to divide the entire range among the different classes of stock. Ilaring ascertained the area of Based upon nor- range arailable for each class of stock, the number it
mal conditions.

will support will be determined. This estimate should, as far as possible, be based upon the normal condition of the range and should not be varied from year to year to meet departures from normal, except as a measure of Forest protection. Increased capacity due to natural conditions known to be abnomal should not be accepted as grounds for increases in the numbers of stock. The allotment should in every case be low enough to prevent lamage to the Forest.

In preparing estimates, the Supervisor will not consider the carrying capacity of the following classes of land:

Lands not consid Patented lands of any character.

Subsisting mining locations.

Entries under United States land laws.

Indian allotments.

State lands granted or selected under Acts of Congress.

Railroad lands within primary grant limits.

Survered and selected railroad lands within indemnity limits or other selections provided for by law.

Subsisting squatter's claims.

The carrying capacity of all Government lands within the National Forests not otherwise reserved or closed to grazing

Land Included in for protective purposes and unsurvered school secestimate. $\quad$ tions or unsurveyed lands within indemnity limits of railroad grants should be considered in the estimate. 
The permits issued by the Forest Service do not grant authority to graze stock upon any except National Forest lands,

Grazing on private lands.

and the Government is not responsible for the intrusion of permitted stock upon private lands. Controversies must be settled between the owner of the stock and the owner of the land under the State laws and in the State courts. 'They are not violations of the regulations and do not require action by the Forest Service.

Grazing periods will be established for each National Forest to meet Grazing periods. the general needs of the people and to secure an economical use of the forage. No reduction in grazing fees will be made when the stock do not graze upon the National Forest during the entire period allowed, nor will an increased number of stock be allowerl to enter the Forest for this reason.

The Supervisor may allow stock to enter not more than 15 days in advance of the date fixed for the beginning of a Extension by su- grazing period, or allow it to remain 15 days after the
pervisor.

expiration without additional charge, when the needs of the pcople demand such action and the condition of the range warrants. The arditional time will not be stated in the permit, but permission to enter before or remain after the regularly established dates will be given either by general notice or by a letter written to the applicant.

In fixing the grazing periods, an endeavor is made to make them Points to consider. meet local conditions and to allow grazing when the particular range in question can be used to the best advantage without injury to the Forest. It is inadrisable to hold stock on winter ranges in feed lots after the range within a Forest is ready for use. It is still more inadvisable to allow stock on Forest ranges before the feed has started, or while the range is so wet that the stock will cause injury to both forage and tree growtl. The condition of the range rather than the desires of the applicants must determine the period. Supervisors should endeavor to recommend seasons which secure the best use of the range without damage.

When grazing periods have been fixed by the Forester or the District

special seasons. Forester, stockmen will be required to secure permit and pay the fee for the full period. Special seasons can be allowed only in cases where the circumstances render such action absolutely necessary. For example, if a certain range will support 10,000 head of sheep from. June 1 to October 31 , its incomplete utilization means a loss of forage values, a loss of revenue to the Government, and a loss of opportunity by others than the permittees to put stock on the range.

On Forests where all controversies have been settled and conditions are such that under ordinary circumstances no Five-year applica-
tions.

grazing areas, or the number of stock allowed, the Supervisor may recommend the acceptance of five-year applications, which, upon approval by the District Forester, will be authorized by the Secretary of Agriculture. The permit will be issued annually and the approval of the application for a five-rear period will only guarantce a rencwal from year to year during the five-year period in the event that grazing is authorized by the Secretary of Agriculture, and there is no cancellation of the permit by him. 
All applications for grazing during a term of years which are Annual reduction. approved for more than the protective limit number of stock will be subject to an annual reduction not exceeding 5 per cent to provide for the issuance of permits to new settlers within or in the immediate vicinity of the National Forest, and to any additional reduction which niay be necessary to stop damage to the Forest. Applications for the renewal of permits at the expiration of the term of years, if approved, will be subject to such reduction as may be necessary to provide for the issuance of permits to other new settlers or new owners.

Permits during a term of years will not be authorized on Forests

When issued.

where it is apparent that the number of stock using the Forest must be materially reduced to stop damage to lange or Forest, or where radical changes may be necessary to adjust the rights of permittees.

Since the approval of applications for permits during five-year Approval of uses. periods is entirely for the purpose of giving better service to the stockmen, the system should not be recommended unless it meets with the approval of a reasonable number of the users of the Forest. Supervisors who have been authorized to approve applications for term permits need not insist upon their acceptance if the stockmen do not care to take advantage of the privilege or, having done so, desire to discontinue it.

Ionthly permits will be authorized only for winter grazing where Monthly permits. special conditions warrant it. Despite the fact that Monthly permits. they may be more convenient for the permittees, there are several factors which render the general issuance of permits on a monthly basis impracticable from an administrative viewpoint. The first is that the practice will result in a disregard of the periods of use to which the ranges are naturally adapted, with consequent incomplete utilization, alternate understocking and overstocking, loss of range capacity, loss of control, and loss of revenue. Another objectionable feature of the monthly pernit system is that it would require each langer to keep account of the dates upon which each permit began and ended, and each Supervisor to maintain a similar

Not practical. record. Such permits would necessarily be subject to extension and additional parments would be required. For these reasons special seasons will not be allowed unless demanded by exceptional conditions.

Winter ranges should not be allotted for use during the summer if winter ranges. such action will prevent their proper use during the winter by settlers residing in or near the Forest who are dependent upon such ranges for wintering their stock. A range which can not be used during the summer season but forms a part of the winter range can not be classified as an unused range in the sense that term is used when Supervisors are authorized to allow permits for increased numbers of stock contingent upon the development of unused ranges by the creation of new sources of water supply, etc.

Upon receipt in the District office of the Supervisor's annual plan

Procedure. the grazing section will be referred to the office of Grazing: The Assistant District Forester in charge will review the report of grazing conditions and pass upon the recomDistrict office. mendations. He will then prepare a memorandum to the Forester recommending the number of each class of stock to be authorized upon the Forest during the following 
season. A letter for the signature of the District Forester to the Supervisor will then be prepared giving detailed instructions for the handling of the grazing during the coming season and covering the following points:

1. 'The number of stock of each class autlıorized.

2. The grazing periods.

3. The grazing t'ees.

4. Allotment of stock.

5. Special points of policy or administration.

6. Instructions for adrertising.

Two carbons of this letter undated and signed by the District Foresterand bearing a space for the Forester's approval, together with the District Forester's memorandum and a copy of the grazing section of the Supervisor's annual Forest plan, will be forwarded to the Forester, the original of the District Forester's letter being held in a waiting file.

After its receipt in Washington and after the authorization for washington office. grazing has been signed by the Secretary of Agriculthe District Forester will be notified br wire and the approved carbon of his letter mailed to him. On receipt of the telegraphic approval he will date and mail his instructions to the Supervisor after making the proper entries on the authorization record card. (Form 404.) If modifications of the District Forester's letters are required he will be notified by letter and will change his instruetions to the Supervisor accordingly. 


\section{STOCK EXEMPT FROM PERMIT. (Reg. G-2.)}

No stock may be grazed without a permit, except milch or work animals which are in actual use. A settler owning only 10 head or less of stock which are neither milch nor work animals will be required to apply for permit and pay the grazing fees, while a settler owning any number of stock will be allowed to graze 10 head of milch or work animals without permit and free of charge.

The privilege must not be abused, but, on the other hand, some discretion may be used in the interpretation of the Discretion of su- term "milch or work animals." 'The settler's family
pervisors. may be using all the milk produced or he may be operating a dairy. Saddle animals may be used for handling stock grazel under permit and at the same time be stock lorses which are bred or sold by the permittee as a part ol his stork business. Trork horses mar be used in timber sales or improrement work for a part of the season and lor other purposes during the remainder of the time. Milch cows may dry up and rum on the range during a part of the season. The determination of whether an exemption may or may not be allowed rests with the Supervisor, the only restriction being that each class of animals must be used for the purposes mentioned at least during a part of each year, or else must be covered by a grazing permit. A saclle horse not in use and turned out to graze during any entire established season should be covered by permit.

In cases where transportation ("ompanies are grazing large numbers of horses which are used in transporting travelers within National Forests, the stock must be corered br permit.

Special concessions may be made by the Secretary of Agriculture to Inciians who are dependent upon the use of the Specialconcessions National Forest ranges for the pasturage of their
to Indians. stock. In all cases where it appears that concessions should be made to Indians a report of the facts will be made by the Supervisor to the District Forester who will forward a copy of the report to the Forester with suitable recommendations.

Rangers will keep a record and inclurle in their report for the quarter ending September 30 each year, a statement Record of stock
grazed without per- of the approximate number of owners and of stock mit. grazed without permit in each district, in order that the Supervisor may consider it in his annual Forest plan. 


\section{DISTRICTS AND DIVISIONS. (Reg. G-3.)}

The grazing of any class of stock upon any part of a National Forest is allowed under anthority of the Secretary of Agriculture. By authority of the act of Jume 4, 1897, regulations of the Secretary of Agriculture govern the use of public lands within the National Forests and are supreme, even though the State law is in conflict with them. When not in conflict with the Federal law, the State law is effective.

It is within the authority of the Supcrvisor to close an area from all Exclusion of stock. grazing, to reduce the number of stock allowed upon it, or to prohibit its use by certain classes of stock when the silvicultural needs of the Forest demand it. For instance, sheep may be excluded from a timber-sale area for a certain number of years affer cutting; or, in a vear of scarcity of mast, hous (otherwise permitted) may be exchuded from the oak type. Where planting operations are being carried on, it will usually be necessary to exclude all classes of stock.

If silvical investigations show that grazing is responsible for the scantiness or lack of reproduction over a considerable area, a portion of it may be withdrawn from range use until young growth has become established, several years hater another portion, and so on until the whole area has been treated. It is desirable, of course, to scenre the welfare of the Forest with the least possible friction or interference with the stock interests. When it becomes necessary to prohibit all grazing on an area of such an extent as to necessitate a reduction of the number of stock allowed on the Forest for the purpose of forest protection or to protect the water supply of a community, the Supervisor should request an investigation from the District oflice. If it is found necessary, the Supervisor, with the District Forester's approral, will take the action. Where action of this sort can not be oflected by a shift in ranges but will result in a cut in the number allowed a permittee or in the entire exclusion of his stock, copies of the letters rejecting the application or amending a permit will be sent the District office with necessary explanations in order that the District Forester may be in a position to answer complaints. Where the cancellation of a permit is entailed, the District Forester will take the action. Except in emergency cases closures should be made to take efiect at the beginning of the grazing season and outstanding permits allowed to stand through the period granted.

When any area within a National Forest contains a growth of poisonous plants in such quantity as to make dan-

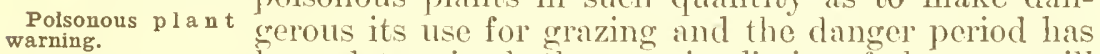

been determined, the exterior limits of the arca will be posted with warning notices (Form 766) cantioning stockmen against allowing their stock to graze within the area during the time when the poisonous plant is dangerous. 
The ranges within the National Forests should be used by the kind of stock for which they are best adapted, except Best use of each when this would not be consistent with the welfare class of range. of the local residents or the proper protection of the Forests. When an application is received for a kind of stock not previously allowed to graze upon a range, the Supervisor should determine, first, whether the change can be made without injury to the Forest or the flow of streams; second, to which class of stock the range is best adapted; and, third, whether the change will be detrimental to the interests of the people residing in the vicinity of the range. The change will be made by the District Forester only when all three conditions are farorable.

For convenience of administration, Forests will be divided into Range distrcts. grazing districts. A typical Forest with an area of Range districts. 1,000,000 acres should usually be divided into from four to six districts, which may be natural grazing units, natural administrative units, or parts of the Forest used by different classes of stock growers or different classes of stock. Wherever possible they will coincide with the lines of the arministrative districts.

These should also be divided into grazing divisions which should Range dlvision. be natural grazing units defined by topographic boundaries with their limits determined largely by the class of stock which is to use them. Cattle and horses ordinarily graze both ways from a stream but seldom cross the summits of the surrounding ridges. Sheep and goats ordinarily graze the crest and slopes of a ridge or mountain but will cross none but shallow streams except on bridges. This should be kept in mind in fixing range boundary lines. Dirisions, being smaller than a district, should usually be for the use of one class of stock and should be designated by well-known local names, such as "Mormon Iake Division." These range divisions may, where adrisable, be divided into individual ranges.

Cattle and horses will be allotted individual ranges when topoIndividual range graphic conditions and methods of handling make it
practicable, but sheep and goats will be in every case, unless unusual cireumstances prevent. The confinement of cattle or horses to individual ranges in a flat country would, of course, necessitate constant riding and increase the cost of handling and is therefore inadvisable. When cattle and horses are assigned individual ranges, the permittees will be required to make a reasonable eflort to keep their st ock within the limits of their range divisions.

The mamner in which sheep and goats are handled makes individual allotments both practicable and desirable. The mixing of herds and the consequent loss of lambs are avoided and each permittee is encouraged to improve range conditions by better methods of handling his stock. The lines of individual sheep allotments should be as clearly defined as possible and every effort should be made to have them thoroughly understood by the herders and camp tenders immediately after the sheep enter the range. A full description should be written in or on the back of the permit, and the boundaries should be marked where practicable with posters. (Form 222.) When range conditions are fairly well settled the practice of furnishing each permittee with a copy of a map showing his own 
and the surrounding ranges is an excellent one. In making individual range allotments the number of eattle and horses which will stray upon them must be considered and proper allowance made for this excess.

Whenever it appears necessary for stock to cross regularly any

Driveways. portion of a National Forest the Supervisor will report the fact, with a deseription of the regular route traveled, the width of driveway necessary to allow the proper grazing of stock en ronte, the number and class of stock which will probably cross, and the number of dars required for crossing.

Upon receipt of such a report, if the circumstances warrant, and Establlshed by grazing upon the area of the kind of stock involved
District Forester. Forester will establish the driveway and define the rights to be granted.

Permits will be required for stock crossing the Forest on a regular driveway.

If occasion demands, rangers may be detailed to accompany the stock and see that there is no delay or trespassing.

The driveway should be as short, as easy of passage and aceess as the character of the country will permit. It should also be established with care for the interests of permittees using adjoining ranges, and it is most important that it should be properly marked with posters along the exterior limits, as suits and prosecutions for straying therefrom can not easily be maintained in the absence of such notices. 
The full grazing fee will be charged on all animals under six months of age which are not the natural increase of stock upon which the fees are paid.

Grazing permits for the summer season may be extended to eover the entire year whenerer there is winter range availExtension of per- able within the National Forest, upon the payment
mits. of the difference between the summer and yearlong rates on stock covered by the original permit and on all animals which have reached the age of 6 months during the summer period.

In the extension of pernits for the summer season to cover the yearlong period, supplemental permits for the number of stock which have reached the age of 6 months, in excess of the number covered by the permit for the summer season, may be issued whenever this will not result in injury to the Forest.

Any increase in the number of stock allowed under such an extension is temporary, and the applicant's preference for the following year will be based on his original permit.

In determining the rates for periods less than one year, no division of less than one-fourth of 1 cent will be made in the rates for sheep, goats, or swine, or of less than 1 cent in the rates for cattle and horses. For eximple, if in computing the rate for a short period on sheep the result obtained is 6.8 the rate will be fixed at $6 \frac{3}{4}$ cents, but if the result is 6.9 the rate will be fixed at 7 cents. Under the same plan if the result obtained in computing the rate for a short period on cattle is 28.5 , the rate will be fixed at 28 cents, but if the result is 28.6 the rate will be fixed at 29 cents.

There is no law which authorizes the leasing of National Forest lands for grazing purposes and there are several reasons why the use of National Forest ranges under an acreage leasc system is impracticable. It would greatly inerease the diflieulty of proper silvical development, prevent a proper use of ranges under abnormal natural conditions, and tend to exclude the smallest owners. Adequate protection of the Forest would be rendered diflicult if not impossible because a lease eren though filled with careful restrictions would give the lessee some right to dictate the use to which the area would be put. During the tenure of the lease no part of the tract could be closed to grazing cven though the necessity was urgent to prevent the destruction of seedlings, to secure reproduction on cut-over or burned areas, or to proteet important watersheds. The privilege would be a fixed instead of a flexible one, and if during the period forage was destroyed by fire, insects, or other eause the stock would have to be removed from the Forest instead of being transferred temporarily to another range. The leasing srstem would practically result in a number of individual allotments equal to the number of permittees and this would tend to shut out the small owner because he could not afford to hold his 
stock upon the small area to which he would be entitled. Fencing of the leased areas would necessitate leases for a term of rears, and term leases would not only hamper Forest management, but also prechude recognition of new applicants who might be entitled to range.

The majority of the National Forest users are small owners who prefer the right to oraze a fixed number of stock rather than the right to nse a specifiol range, with a maximum but no minimum limit.

The rates rhareed for sheep as shown in Reg. G-t are, when the yuality of the range and adrantages are equal, 30

charges for sheep. per' crint of the rates charged for cattle for the following reasons:

First. The proportionate number of stock under 6 months of axe grazed frec on mormits is much greater with sheep than with eatte. In the feed lot the amount of feed repuired for one cow will support (eight shear). (On the National Forest range, where only the grown stork is counted, the proportion is reduced to on" to five, because the proportion of lambs to the old stock is much greater than the proportion of calves, and also because lambs mature more rapidly than calves and require mole feed.

Second. Under the customary methods of handling stock upon the rance, sheep are mure destmuctive to the young forest growth than cattle, being herder in bands white cattle are turned loose. The amount of forage destroyed hy trampling by herded animals is also much rreater than the amomi destroyed by animals rumning loose. Careful investiuation has shown that heried animals require form 25 to 50 per cent more range than animals which are turned loose. 'This justifies a further reduction in the comparative charges to the rates for grazing sheep and groats fixed by the regulation.

In ordinary range manacrement it is found that horses require about 25 per cent more range space during a given

Chargesforhorses. period thin is required by cattle. In many localities horses utilize feed that would ofherwize remain umused and consequently often graze upon fully stocked (antle or shcep ranges without any injui'y from orerorazing, but as they are more readily disturbed, travel greater distances and at sreater speed than cattle, they do more tamase to forage and tres growth through trampling and as a result reguire more of the range.

The forace consumed by swine is difficult to compare with that consmmed by cattle, as their feed is mast, roots, and

charges for swine. bulbs, lather than forare grasses and plants, but in to one cow. On aceount of the cost of regulating logr grazing, the very lare proportionate natural increase, and the damage from rooting, 60 to 75 per cent of the rate lor cat tle is cquitable.

I band of dry sheep will not consume as much forage as a band of ewes with lambs, but since they will run and mass Charges for dry to a creater degree the clemand on range is about
sheep. sheep. equal. The high summel' ranges of the National Forests are required to enable ewes to produce the maximum amount of milk to rive the lambs the growth they require to prepare them for market. Therefore as between the two chasses the livgher and better ranges should be given to the ewes and hambs. The absence of lambs 
in a band does not justify any reduction below the rates charged for ewes with lambs, and persons grazing dry sheep will not be given a reduction in rates or an increase in number.

The additional charge of 2 cents per head for the privilege of lambing ewes upon the National Forests is intended to be an ing. extra charge for a special use of the range. It should not be included with the season fee but should be figured separately upon the basis of the number of ewes or does to be lambed or kidiled. The control of suitable lambing grounds is one of the most important factors in successful sheep raising. The intensive method under which sheep must be handled during the lambing season causes more damage to the range than ordinary grazing, and the lambing charge is made for the use of the range for a special purpose which causes more than ordinary damage to the range. It is not on account of the additional feed required by the lambs.

The phrase "for the purpose of lambing or kidding" should be construed to mean the use of a range during the period from the time the first lambs or kirls are born until the herds are made up for summer grazing, or ordinarily the period during which the herd is on the lambing grounds. The mere fact that lambing corrals are located upon patented land within the Forest or upon public lands immediately adjacent will not relieve a permittee from the parment of the lambing charge. Two cents per head will be charged in all cases where drop bands are grazed upon the Forest or where ewe bands enter the Forest immediately after the lambs are dropped and before the herds are made up for the summer. If a lambing ground is located partly within a Forest and partly outside, or on private lands, so that the stock will be grazed on and ofl the Forest during the lambing period, there should be a dirision of the extra charge for lambing on the same basis as the on-and-ofl grazing fee.

While it is true that in some cases ewes or does entering the Forest with lambs or kids af ter the herds are first made up must be confined. to a limited area until the young are able to travel and consequently damage the range to an unusual rxtent, the element of special use and damage is not present and they will be charged for at the regular rate established for sheep and goats for the period. 


\section{PAYIMENTS AND PERMITS. (Reg. G-5.)}

In cases where it is diffirult beforehand to determine the use that can be mate of a privilexo, permits should he issued for the Grazing fees paya- establisherl period which most elosely meats the require-
ble in advance.

ments of the case. Special autherity may be seruled later for refund of the uncarned portion of the loe when the circunstances warrant on the basis of the percentase of use secured by the permitce. Since a refund requires the apploral of the District Forester, permits must not be issued with the understanding that a refund will be mate.

If an emerency requires that stock be allowed to enter the Forest immediately, the District Forester may authorize the Emergency conces- Supervisor to allow the stock to enter upon evidenee slons. that the fee has heen forwarled to the Tnited States Depository, the permit to be issued when notice of receipt of the remittance is receivel. In no case will stock be allowed to entel the Folest before remittance has been made.

The last paragraph of this Regulation should be enfored within the discretion conferred by the reculation. It is not Nonpayment of the intention to bat the applicant from all future use
fees. of the range heeatuse he fails to pay his grazing fee for one season. If he fails and his stock eraze ripon the Forest he becomes a trespasser and may be denierl a permit until he sottles his trespass; or, if he makes application without intendiner to use the range but merely to hold it to the cxchusion of other applicants, he may be denied a pelmit. If his failure to make the required payment does not deprive others of range or necossitate a readjustment of grazing allotments, it may be overlooked and need not be made the grounds for a rejection of an application.

Permits.

Tpon receipt of notice by the Supervisor that the fees lave been pairl a permit will be issued.

When the amount paid is less than the amount due, the Supervisor will notify the applirant to romit the remainder,

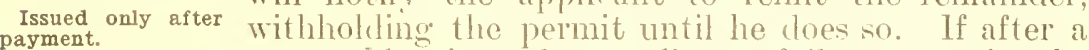
reasonable time the applicant fails to remit the amount due, the superrisor may issue a permit for the number of stock which the fees paid will cover".

Grazing permits will be issued only for authorized periods, except when it is neressary to shorten the period to stop damage to the Forest.

Yearlong permits will begin at the opening of the summer grazing season and end on the day preceding the corresponding date of the following year. 
I'nless the range to be occupied is clearly stated in each permit, a Rangedescription. suit for trespass brought against a permittee for grazing his stock on the ranges of others may fail. The permit will be prepared in triplicate and given the number of Procedure. the application on which it is issued. The original, accompanied by the original letter of transmittal, will be sent the permittee, one copy to the ranger interested, and the third filed in the supervisor's office.

Term permits will show the year for which issued, thus: "Fiveyear period, first year."

The District Forester may in his discretion require copies of permits issued to be sent to him for review. 
REFUNDS. (Reg. G-6.)

Whenever payment in excess of the amount due is made, the amount overpaid will be refumled. Applications for the refund of monevs in excess of the amount due

Excess payments. must be accompanied by a copy of the grazing permit issued, show-
ing the amount received and the number of stock and grazing period covered by the permit.

All claims for refunds will be considered in accordance with Regulation $\mathrm{G}-6$.

Applications for the refund of money paid on account of a grazing permit must be accompanied by a statement giving Grounds for re- the reasons for not using the permit. 'This may
fund. be either the written statement of the permittee ol' a report by a Forest oflicer who has looked up the case.

Refunds will be made to a person who applies for a permit and does not use it only when the nonuse is caused by some circumstance over which he has no control. Unusual climatic conditions, floods, high water in streams, heavy snow, etr., or infectious disease causing quarantine by Federal or State authority, loss of stock caused by poison, disease, railroad wrecks, or in some unusual manner are all good reasons for refund. In all cases of unusual loss where it is either impracticable or impossible for the applicant to secure other stock, a refund may be mate, but if the stock can be replaced this should be required, as in the case where a portion of the stock has been sold and removed from the range.

An equitable portion of the grazing fees may be refunded when a permittee is prevented from enjoying the full use of his range by reason of trespassing stock entering upon it or on account of an error by a Forest officer.

Refunds will be made on arcount of stock having been sold only sale of stock. when the preference in renewal of the permit is waived by the original owner to the Government and the purchaser is allowed a permit. In such a case the fees on the number of stock repermitted may be refunded to the original permittee on his request.

The amount which will be refunded will not exceed the amount of the fees due on the permit issued to the purchaser. The difference, if any, between the amount paid on the original permit and the amount due on the new permit will not be refunded. A permittee who sells his stock under conditions which justify a full renewal of the permit to the purchaser, and signs a waiver to its renewal to himself (Form 763), is entitled to a refund of the full amount paid. If the conditions justify a lenewal for only 80 per cent of the number of stock covered by the original permit, then 80 per cent of the original payment will be refunded. 
Persons who make application to graze stock which they do not own but intend to purchase will not be entitled to a Fallure to pur- refund because they fail to secure the stock. They
chase stock. chase stock. may, however, reserve the right to place stock upon the range at any time during the period allowed by the permit.

In many cases applications are submitted for the privilege of Stock to be pur-
hased. grazing stock which the applicant expects to buy later in the season, and the Supervisor approves the application and issues the permit. Later developments lead the applicant to believe that more money can be made by some other action and he requests a refund of the fees paid. Such refunds should not be approved. By the issuance of a permit the Forest Service has done its part in reserving sufficient range for the number of stock covered. In such cases the range is at the disposition of the permittee during the period covered by the permit and he has the right to place the stock upon it at any time during the season. His failure to avail himself of the privilege does not constitute grounds for a refund.

Speculation in the use of the Forests can only be prevented by a strict enforcement of this rule.

When payment of a grazing fee is required, the Forest officer will Procedure pay-furnish the applicant with a letter of transmittal ments and refunds. (Form 861-G), which must accompany the remittance to the United States Depository. A duplicate will be be sent to the Fees. District Forester by the Supervisor and a triplicate der "Payments and permits," p. 30.)

Upon receipt by the Supervisor of an application for a refund and Refunds. statement of the reasons therefor, he will forward it to the District Forester with a recommendation for its approval or rejection. Requests for refunds which are sent in error to the District office will be referred to the Supervisor concerned for report and recommendation. The District Forester will decide whether or not the refund will be made. If the request for a refund is approved, the Supervisor will be so informed and a Form A voucher, prepared for the signature of the person to whom the refund is to be made, will accompany the letter. The amount of the refund and the date of the voucher will be noted upon the duplicate letter of transmittal (Form S61-G).

When the voucher is returned signed it will be compared with the duplicate letter of transmittal, on which will be entered "Checked," with the date. The voucher will then be approved by the Chief of Grazing and sent to Accounts for payment.

If the request is disapproved, the Supervisor will be informed accordingly. 


\section{QUALIFICATION OF APPLICANTS. (Reg. G-7.)}

The use of the National Forests for grazing purposes is in the discretion of the Sccretary of Agriculture. There is no Grazing privilege law which gives an individual or corporation the right
not transferable. not transferable. - to graze stock upon National Forest lands, and the grazing use of such lands may be allowed by the Secretary of Agriculture only as a personal and nontransferable privilege. This privilege is a temporary one, allowable unler the law only when it does not interfere with the purposes for which the National Forests are created. It is nontransferable because it is based upon the possession of certain qualifications peculiar to the permittee.

By long use of the public lands of the United States for grazing pur-

Prior occupancy. poses, stock owners have been suffered to graze their stock upon such lands under certain conditions of occupancy, residence, and ownership of improved land or water rights. This use, continued throughout a long period of years, has in the absence of Congressional legislation been commonly accepted in many communities, even receiving the recognition of certain of the courts. It is, however, allowed only by passive consent of the United States. By force of the Presidential proclamation creating a National Forest, such passive consent ceases and is superseded by definite regulations by the Secretary of Agriculture prescribed under tho authority of Congress. Grazing stock upon the Forests, except in accordance with these regulations, is trespass against the United States.

No one can acquire a right to the use of National Forest range, but Legal rights. he may acquire a preference in the allotment of grazing privileges. This preference does not entitle him to continued use of a certain part of a Forest, but only to a preference over other applicants less entitled to consideration, in the use of the ranges open to the class of stock which he wishes to graze. These preferences of their very nature possess relative degrees of superiority and consequently have a number of gradations.

Certain grazers may be given preferences in ranges secured by prior value of privilege. use and occupancy, supplemented in many cases by value of privilege. heary investments in improved property and water rights. These preferences have a distinct value, and the failure to recognize them would mean a financial loss by reducing the number of stock which may be grazed and by the depreciation in the ralue of lands and improrements. Two conditions only would justify such. action-when necessary to stop damage to the Forest, and when necessary to promote the settlement and cultivation of farming lands tributary to the Forest through a wider distribution of the grazing privilege. It is incumbent on the Service to allot limited privileges to actual settlers in order to accomplish this latter purpose, but a promiscuous division of grazing privileges among a number of owners $86104^{\circ}-11-3$ 
who are neither new settlers nor dependent upon the range is unwarranted. The policy of recognizing new settlers upon lands in or adjoining Forests who require limited grazing privileges to make their home successful will tend to equalize the number of stock allowed under each permit for an increase in the number allowed new owners to bring them up to a profitable basis, and must be accompanied by a reduction in the number allowed larger owners. New class B applicants should be granted permits only when the Forest is not fully stocked, and no reductions in the permits of other users will be necessary to accommodate them.

Preference may be secured in the following ways:

(a) By prior use and occupancy of lands included within a National Forest.

(b) By local residence, ownership of improved ranch property, and How preferences dependence upon the range for a livelihood. (See are gained. instructions under "Permits to new owners," p. 45.)

(c) By the renewal of a permit formerly held by a copartnership or corporation to each individual member for a number of stock equal to his share in the original permit. (See instructions under "Renewal of permits," p.47)

(d) By the purchase of a permittee's stock or ranches, or both, under circumstances justifying a renewal. (See instructions under "Renewal of permits," p. 47.)

(e) By inheritance of a permittec's stock or ranches, or both, under circumstances justifying a renewal of the permit. (See instructions under "Preferences," p.37.)

The regular use of a range during its open scason for several suc-

Prior use. cessive years, before creation of a Forest, and under grazing permit thereafter, is what is meant by "prior" use" or "regular occupancy." So far as is consistent with other conditions, preference will be given to those who have continuously used the range for the longest period. 
Applicants for grazing permits will be giren preference in the following order:

Small near-by nuncrs. - A class 1 owner is one who does not own

Class A.

more than the protective limit number of stock established for the Forest, who owns and resides upon an improved ranch within or adjacent to the Forest, and who is dependent upon the use of the National Forest range in connection with his ranch property. Entil the protective limit is defined it is within the discretion of the Supervisor to determine whether an applicant is a large or small owner. A firm or corporation can not be considered as a class $\Lambda$ applicant but may be allowed exemption from reduction below the protective limit.

All other regular occupants of the range.--Class B includes owners of

Class B. improved ranch property and stock in excess of the protective limit, and owners of stock either above or below the protective limit who do not own improved ranch property. Copartnerships, companies, and corporations nay be class B owners. All permittces in this class must secure their permits on the basis of prior use and occupaney or the purchase of the stock and ranches of persons holding permits.

There may be several grades of class B applicants. One who owns a large amount of improved ranch property, or one who resides in the vicinity of the Forest, or who has used the range during a long period of years, or who feeds his stock during the winter, may be given preference over one who does not own improved ranch property adjacent to the Forest, or who resides at a distance from the Forest, (1) who has only used the range a few rears, or who winters his stock on the range. Class $B$ permittees are subject to slicling-scale reductions, although usually such reductions are not applied to permits for less than the protective limit.

Owners of transicnt stock. - Class C embraces all grazing applicants Class C. not falling within classes $A$ and $B$. A speculator who buys stock and places it upon the range at intervals, or the nomadic stockman with no fixed range who triils his stock to widely separated ranges would be class C owners. Class C applicants will be entirely excluded from the Forest before any reduction is made upon class B applicants.

An applicant's status is determined by the total number of all classes of stock owned by him. He can not be a Status determined class A cattle owner and a class B sheep owner. If
by holdings.

he owns either class of stock in cxcess of the protective limit for that class he is a class B owner, or if he owns a per cent of the cattle protective limit and also a per cent of the sheep protective limit, which combined exceed 100 per cent, he is in class B. For 
example, the protective limit being 100 head for eattle and 1,200 head for sheep, if he owned 50 head of cattle and 500 head of sheep (92 per cent) he wothl be in class $A$, but if he owned 75 head of cattle and 750 head of sheep (137 per cent) he would be in class B. An applicant owning sheep and cattle may, however, be in both class B and class $\mathrm{C}$.

By ranch property in the grazing regulations and instructions is meant lands producing cultivated crops which are ownership of ranch used for feeding live stock. In localities where the property. production of feed is not a requisite to the stock business, the ownership of spring and fall range or lambing grounds by a bona fide local resident dependent upon the use of the range, should be given nearly the same if not equal weight with the ownership of cultivated lands. The same is true of the ownership of water rights which control adjoining National Forest range. In renewals to purchasers of permitted stock the ownership of spring and fall range or water rights closely related to the use of National Forest range may be given equal weight with improved ranch property. Property of this sort must be commensurate with the number of stoek and artually dependent for its value upon National Forest range. To illustrate, a spring and fall range and lambing ground sufficient for 1,000 head of sheep might justify the approval of an application for a permit to graze 1,000 or less sheep upon a National Forest during the summer season, but not of an application to graze 2,000 head of sheep during the summer season or to lamb and graze 1,000 hearl of sheep during the spring and fall seasons.

A person will be considered dependent upon the use of the National Forest range when the Forest lands adjacent to his Dependence upon own contain the only available stock range, and the
range.

grazing of a limited number of stock is essential to his success in the development of his land.

Resilence is simply an index in determining the degree of dependence. A person residing at a distance from a National Forest must have other ranges open to him and can not be considered so dependent upon Forest range as one residing near by.

Cooperative associations are formed to facilitate the handling of cooperative asso- stock and reluce the cost, each member retaining his ciations.

inclivichal grazing preference and running his stoek under his own name and brand.

Such a cooperative association may make one application for the entire number of stock owned by its members, if the application is signed by each one and is accompanied by a statement showing the number and brands of the stock owned by each. The approval of the application will be based upon the qualifications of the individual members. When the association disbands each member may renew his permit upon the basis of the number of stock which he grazed prior to the organization of the association with a proportionate share of any subsecuent increases or decreases in the association permit.

If the association uses a common brand so that individual omership can not be cletermined, or if its profits are distributed on a pro rata basis, it will be allowed the same privileges as a corporation, and entitled to recognition only when the members waive their individual preferences to the Government. 
A firm, copartnership, or corporation must be in either class B or

Firms, copartnerships, and corporations. class $C$, for it can not be in class $\Lambda$. It can establish a grazing preference in two ways. By use and occupaney of the lands included within the Forest prior to its creation, and by the purehase of the stock or ranches or both of a permittee under conditions justifying a renewal of the permit.

A corporation can not be given the same consideration as an individual owner. Between two corporations-one composed of local residents and the other of nonresidents--preference will be given the local corporation. In no case will the individuality of the members of a corporation be considered in competition with independent individual owners.

If the State laws give a married woman the right of independent Married women. ownership of real estate and live stock and she possesses the other qualifications which entitle her to a grazing permit, her application may be approved regardless of the grazing privileges held by her husband. If, however, the laws of the State provide that all property be held in common, the woman would be considered as owning the number of stock for which her husband holds permit.

Where the wife applies to graze stock she has purchased, again the State law on ownership would govern. If independent ownership is allowed and the purchase of the stock and ranches is strictly the wife's transaction, a renewal of the permit may be allowed even though the combined holdings of the husband and wife exceed the maximum limit. If the State laws require all property to be owned in common, then a permit can not be renewed on the purchased stock which would make the combined holdings of husband and wife exceed the maximum limit.

An ummarried roman of legal age is entitled to full consideration Unmarried women. as a new applicant if she desires to take out a grazing permit.

Minors who were not occupants of the range at the time of the Minors. creation of the Forest will not be erantecl permits except when they are at the head of a family dependent upon them for support. Minors under the control of parents or guardians may be granted permits if such action will not necessitate reduction in existing permits or the denial of applications of other class A owners.

Pending the division of an estate, a full renewal of the permit held by the deceased should be allowed in the name of the

Renewal to estates. estate and the duly appointed administrator. Upon the issue of a court decree lividing the estate the privileges allowed the estate will be granted the beneficiaries under the rule gorerning the renewal of permits on account of purchase, except that the permit for that portion of the stock allotted by the court decree to the widow or minor heirs will not be subject to the reduction made in the renewal of permits to purchasers.

As a general rule an heir or devisee should be considered as in the same class with one who has purchased stock crazed under permit. Applications of heirs will be adjudged on the basis of the class (A, B, or C) qualifications of the applicants. 
Resident owners of stock which belong in the State or Territory in Nonresidents. which a National Forest is located will be given the preference, but owners of stock coming from adjoining States will also be considered when the Forest is the natural lange of the stock, and the nonresident owners are dependent upon it.

Caution should be exercised in admitting transient stock to ranges which are not fully occupied by the stock of regular

Transient owners. user's. A permit may be granted an owner who is a transient resident in the locality with the understanding that it gives no permanent grazing preference.

A person leasing stock or running it on shares or herding it for the permittee is regarded as an employee only and he can Lessees and herdnot be allowed any preference in the use of the range by virtue of the fact that he has run the stock under lease or on shares or has handled it for the owner. The status of the owner determines all preferences allowed in the issuance of grazing permits.

Grazing preferences ean only be retained by a continual use of a range. Applicants who apply to graze a reduced

Retention of pref- number of stock can not expect range to be reserved erences. for them for a higher number later on. In the case of a roluntary reduction other applications may be approved for the number by which the first permit was reduced. The preferenee thus arined will not be surendered because the first permittee applies a year or two latei to graze the original number of stock.

Applications from persons with established preferences will not be disapproved for nonuse of the range during one year

Nonuse of range. if a statement giving satisfactory reasons is filed witl the Supervisor before the opening of the grazing period, so that the Supervisor may make temporary disposition of the vacant range. Permits allowing the temporary use of such a range shomld stipulate that a renewal of the permit may not be allowed during the following year.

Nonuse of a range by a new applicant will cause him to forfeit all preference which has been allowed him.

Permittees employel by the State or Government, wishing to discontinue the use of the range without losing their

State or Federal preferences, may do so by filing a statement of their employees. employment and probable duration, the disposition made of their stock, and authorizing the Supervisor to dispose of their range privileges. Upon the expiration of their term of service their preference in the allotment of permits may be restored to them subject to any reductions or restrictions effective at the date of their reapplication.

Except in the case of Federal or State employees, nonuse of the range for more than one year will cause the permittee to lose all preference on account of prior use of the rauge.

Where the renewal of a permit is allowed a purchaser of stock, a written waiver (Form 763) of all elaims by the original Waiver of prefer- permittee to a renewal of the permit for the stock ence. sold should be filed with the Supervisor. This leares the Supervisor free to renew the permit to the purchaser, if such action is justified, but no action should be taken by the Supervisor which in any way obligates the Forest Service to allow a renewal of the permit. 
A person who has signed a waiver of grazing privileges can acquire them again only as a new applicant.

If a mortgage on stock is foreclosed, the permittee does not lose his preference in a permit for the following season

Foreclosure of and unless he has returned his permit to the Supermortgage. visor and consented to the issuance of a permit to the mortgagor as a purchaser for the remainder of the grazing period, he may replace the stock. The person foreclosing the mortgage may be allowed, with the consent of the permittee, to continue grazing the stock during the remainder of the current grazing period under the same conditions as a purchaser, but secures no privileges of renewal unless the owner of the stock signs a waiver of his renewal preferences.

The foreclosure of a mortgage covering both stock and ranch will not cause a permittce to lose the preference allowed him in use of the range if he replaces the stock and secures another ranch equally dependent upon the range.

The fact that a person has been indicted for the violation of a State Indictment. or Federal law does not justify the disapproval of his grazing application unless he is charged with trespass upon a National Forest. 'The Forest Service will not anticipate the dlecision of the court.

An applicant who does not own the stock for which permit is Nonownership. desired and whose prior use of the range entitles him to consideration, may secure a grazing permit on his certification that the stock will be purchased.

A grazing preference can be transferred from one Forest to another only when the first Forest is overstocked and the Transfer toanother second Forest is understocked and the transfer will
Forest. be generally beneficial. In this event a transfer may be allowed if both Supervisors approve. 


\section{NOTIFICATION OF APPLICANTS. (Reg. G-9.)}

All persons who held permits during the previous year will be notified by postal card (Form 153) of the date upon which applications for grazing permits must be filed with the Supervisor.

Applieations must be received, range allotments made, and permits issued before the beginning of the grazing season. 'This necessitates fixing a date sufficiently far in advance to enable the Supervisor to complete the work of issuing the permits. The date having been widely published, it will be assumed that the applieations on file that day represent all the users of the Forest range entitled to consideration, and the Supervisor may proceed to allot the grazing privileges. The applications having been acted upon and the Action on applica- notices of approval forwarded, no changes will be
tions. made to accommodate persons who failed to file their applications in time, unless their failure was caused by cireumstances which, in the Supervisor's opinion, warrant a readjustment of range allotments. Negligence or failure to exercise ordinary diligenee will not be considered a satisfactory reason for the acceptance of an application after the date set.

In case the total number of any kind of stock applied for before the date which has been set does not equal the number authorized to graze on the Forest, applications may be approved at any time until this figure has been reached.

Supervisors should acknowledge the receipt of applieations by postal card. (Form 303.)

Supervisor's must not notify applieants of the approval of their applications before the date set for their consideration. 
When a single range used by an applicant is located in two adjoining Forests, either Supervisor, with the consent of Range in two For- the other, may issue the pernit with the understanding
ests. that stock is to be grazed upon both forests. 'Two copies will be sent to the other Supervisor.

Persons who desire to graze the same class of stock upon the range Appucations for during more than one established period may submit more than one one application for the entire number of stock, showperiod. ing the number which will be grazed during each period.

New applicants are classified upon the total number of stock owned by them, while permittees seeking a renewal

Statement of ownare judged by the number of stock for which they held permit during the preceding year. New appliership. cants, therefore, should state the total number of stock owned. Old permittees need state only the number of stock for which application for permit is made.

When applications for permits are made to graze stock which it is intended to purchase, a statement to that effect will be made on the application blank.

When necessary an applicant may be required to furnish a certified statement showing the name, residence, and interest of any other person in the stock covered by his application. The District Forester may require firms or corporations to furnish a certifier statement of the name and residence of all members or stockholders.

Grazing permits will not be issued to new firms or corporations

when the nembers or stockholders of such firms or Partnerships or corporations hold permits to graze numbers of stock
corporations. which combined exceed the maximum limit estab)lished for the Forest. The consolidation of permits will not be allowed when the combined number of stock is more than the maximum limit.

If the Supervisor has reason to believe that a new applicant, or one seeking the renewal of a permit on account of purchase, aheady holds an interest in a company grazing stock under permit he may require this information, or may require it if there is a question of preference between two companies or corporations.

In case the applications have not reached the total number of stock

\section{Amendments.} authorized to craze upon the Forest, supplemental Amendments. applications may be approved with the understand-
ing that no permanent range equities accrue for the increase. This understanding should be made a matter of positive record so that it will not be overlooked in subsequent allotments.

When authorized by the Secretary of Agriculture, applications may be approved for permits during a term of not Applications
term permits. more than five years. The permits will be issued term permits. $\quad$ and the grazing fees paid annually on the number of stock for which the application is approved.

Applications for term permits will be cancelled for failure to pay the grazing fees for any one year, or for failure to use the range for more than one year unless unusual circumstances exist. 
Protective limits are established to protect permittees from Protective limits. reductions in the number of stock which they are allowed to graze under permit, to a point where it is inadequate to maintain a home, or is too small to be handled at a profit. The average number of stock which a settler must graze in order to utilize the products of his farm or derive a reasonable profit will be determined upon each Forest and will serve as the basis for the protective limit. In arriving at this a verage number the dependence of settlers upon National Forest ranges will be considered. Where stock growing is the only pursuit in a region, the number of stock guaranteed a settler must be sufficient to support his family. In an agricultural region where the product of the farms is fed to stock, the number should be sufficient to consume the forage produced by the average farm.

Protective limits have been established for various Forests ruming from 25 to 300 head for eattle and horses, and from 500 to 2,000 head for sheep and goats. The limit on sheep is proportionately higher than on cattle because as a general rule the cost of handling is increased by requiring a man to run less than one band. With cattle or horses, which ean be turned loose upon the range, a proportionately smaller number of animals can be run with profit. Under ordinary conditions the arerage number of stock per permit may be the basis for the protective limit of the Forest.

Vilien in the judgment of the District Forester it becomes neeessary for the protection of class A owners, he will establish a Forest protective limit for each lind of stock, and renewals of all permits within such limit will be made without reduction. A holder of a pernit for one class of stock may secure a permit for another elass, providing the number holds the same ratio to the protective limits. For example: 1 holder of a cattle permit for 50 head on a Forest where the protective limit is 100 head may also be allowed a permit to graze 600 sheep if the protective limit on sheep is 1,200 head.

When necessary to prevent monopoly in the use of the range through the purchase of permitted stock and ranches, saximum limits. the Distriet Forester will establish a maximum limit in the number of stock allowed any one applieant. No permittee will be allowed to inerease the number of stoek above this limit. When necessary, reductions in permits for more than the maximum limit will be macle in accordanee with the sliding seale.

Maxinum limits may be absolute or preventive. An absolute limit is the largest number of stoek for which a permit will be issued, regardless of existing priorities. Where an absolute limit is established all permits in excess will be reduced to that limit immediately. Only in extreme cases where the use of a Forest range is intensive, and a large number of deserving applieants must be taken eare of, will an absolute limit be established.

Preventive maximum limits are designed to bring about a better distribution of grazing privileges. Reṇewals of old permits in excess 
of the maximum limit mar be allowed, but the purchase of stock and ranches will not entitle the purchaser to a renewal of permit in excess of it. Exception to this rule may be male by the District Forester when an established outfit holding permit in excess of the maximum limit is sold to a single purchaser.

Orilinarily the maximum limit will he from four to eight times the protective limit. Upon a Forest where the average number per permit is high the maximum limit should be correspondingly high. A safe rule is to set a limit which is not less than double the protective limit and not more than the highest permit.

The maximum limit does not apply to permits issued on account of private lands or to permits issued uncler a cooperative agreement.

Persons owning a less number of stock than the protective limit will be allowed to increase their number gradually Increases and rebut nuy be restrieted in the number added each

year. Old class A user's may increase at once to the ductions. number allowed new applicants. Increases above the protective limit will be allowed only to purchasers of stock and ranches of permit holders, and any such increase will not exceed the maximum limit.

Increases may be allowed in the renewal of permits which are below the protective limit, but on fully stocked Forests the total increase allowed combined with the total number allotted new settlers must not be more than 3 per cent of the allotment except when a surplus in excess of this percentage is created by the reduction on permits renewed to purchasers. The Supervisor will detemine the division of the allotment which will be made between new settlers and persons whose permits are below the protective limit.

Whenever it is found necessary to reduce the number of stoek allowed in any Forest, class $\mathrm{C}$ stock will be excluded before the other

Reductions. classes are reduced. The reduction on a slidingscale basis will then be made on the class B owner's, and class A owners will be exempt from reduction.

Where the reductions are necessary, each National Forest will be considered as a unit. Under unusial conditions, however, reductions may be made in one grazing district or lange division. Reductions will be based upon the number of stock grazed under permit the previous year.

sllding scale.

The following is an example of the ordinary form of sliding scale:

The protective limit having been fixed at 1,200 heald of sheep, all permits for not more than that number may be renewed withorit reduction.

All permits for less than 1,200 sheep may be increased 20 per ("ent, provided none goes above 1,200 head.

All permits for from 1,200 to 2,400 sheep will be reduced lo per cent, provided none goes below 1,200 head.

All permits from 2,400 to 4,800 sheep will be reduced 15 per cent, provided none goes below the highest number allowed in the next lower grade, or 2,160 .

All permits for more than 4,800 will be reduced 20 per cent, provided none goes below the highest number allowed in the next lower grade, or 4,080 head.

Another form of sliding scale reduction which may be adopted is as follows:

All permits may be renewed withont reduction on the first 1,200 head of sheep.

An increase of 20 per cent may be allowed on all permits for less than 1,200 head.

All permitis will be reduced 20 per cent on the number in excess of 1,200 and up to 2,400 head. 
All permits will be reduced 25 per cent on the number in excess of 2,400 and up to 4,800 head.

All permits will be reduced 30 per cent on the number in excess of 4,800 head.

The percentage reduction may be changed under either plan to fit the local conditions.

When a sliding scale reduction figure has been worked out it may be applied in the following manner, raying the pereentages to suit the situation. All applicants who do not own improved ranch property or who are nonresident ranch owners and winter their stock upon the open range will be reduced the full percentage of their class. Resident ranch owners who winter their stock upon the adjoining open range, regular users who purchase winter feed for their stock from resident ranch owners, and nonresident ranch owners whose stock is wintered upon the products of their lands will be reduced 75 per cent of the reduction figure. Owners residing upon their improved ranches and wintering their stock upon the products of their lands will be reduced 50 per cent of the reduction figure.

Term applications for less than the protective limit may be amended Increase in term to allow the same annual increase that is allowed permits. annual applicants until the protective limit is reached.

All applications for grazing during a term of years, which are Reductions in term approved for more than the protective limit, will be permits. granted subject to an annual reduction not exceeding 5 per cent to provide for the issuance of permits to new settlers within, or in the immediate vicinity of, the National Forest, and subject to any additional reduction which may be necessary to stop damage to the Forest.

While the percentage of reduction to provide for new settlers will not exceed 5 per cent, the reduction to stop damage to the Forest may he as large as necessary to secure the result. As term permits are not authorized until the nimber of stock grazed has been reduced to the normal capacity of the Forest, it is not probable that severe reductions will be required.

At the expiration of the term permit the 5 per cent elause to provide for new owners ceasus to he binding on the Service, and the application is subject to any percentage of reduction before it is renewed that is eflective on the Forest at the time. 
PERMITS TO NEW OWNERS. (Reg. G-12.)

Applications from new settlers or beginners on Forests which are Filed six months fully occupied will not be considered unless filed in advance. with the Supervisol at least six months before the begimning of the yearlong grazing season.

A reduction will be necessary to provide for them; therefore it is essential that other users of the Forest be notified of it as soon as possible in order that they can arljust their business to meet it without loss.

When the range is fully occupied, the total number of stock allowed Limited to 3 per begimers in any one year must not exceed 3 per cent cent. of the total allowance for the Forest.

The applications of begimmers will not be approved in any ease where this would necessitate a reduction of more than 20 per cent in the renewal of any permit issued for the previous year.

The applications of beginners who are in class $B$ may be approved Class B beginners. for the number of stock allowed other begimmer's when there is surplus range, and the issuance of a permit will not entail a reduction upon occupants of the range or debar class A applicants.

Upon Forests which are not fully stocked or when there is surplus Number allowed range, applications of beginners mar be allowed for the beginners. full protective limit; when there is not, permits to beginners will be restricted to one-half the protective limit.

When the arerage permit number is less than the protective Average permit limit, the applications of begimers slould be apbelow protective proved for not more than one-fourth the protective limit. limit, and only when the stock will be fed during the winter from the products of the permittee's cultivated land.

The only justification for permits of this sort is when settlers absolutely require grazing privileges in order to market the products of their ranches by feeding them to stock during the winter months.

No applications from beginners will be approved when the arerage permit number is more than 20 per cent below the protective limit. 
A permittee with an established preference may change his resiChange of resi- dence to a point more remote from the Forest without dence. disculualifying for a renewal of permit, provided lie retains his other interests.

A permittee having a range preference based on ranch property Sale of ranch. located in or adjacent to the National Forest may dispose of such ranch property without entirely disqualif ring himself for a renewal, but unless he secures similarly loeated ranch property his classification is changed, and the renewal of the permit should be on the basis of the changed classifieation.

A renewal of permit may be allowed for a class of stock different from that previously grazed. It may require relinquishment of one range and acceptance of another on some other part of the Forest. 'The ratio of exchange will depend on the demand and the capacity of the ranges in question. A permittee grazing cattle upon a heavily stocked range in strong demand may be allowed to Change in class of graze sheep on the same range on a ratio of 4 to 1 .
stock.

If they are to be grazed on a hearily stocked sheep range, the ratio should be 4 to 1 . If on sheep range, but not heavily stocked, the ratio should be not more than 5 to 1 . If on sheep range where there is surplus range arailable, the ratio may be as high as 6 to 1 .

A permittee having an established preference may enter into a partnership agreement with another person not a Partnership agreepermittee, and secure a renewal of his permit in the ment. name of the partnership, the proportionate interest transferred being subject to the rules governing the renewal of permits to purchasers.

A copartnership has a different legal status from that of an incopartnerships corporated company, and in the renewal of permits and partnerships co purchasers it is necessary to lifferentiate between companies.

them. An individual permittee who enters into a copartnership agreement transfers only a part of his interests, consisting of his stock or ranches, or both, to the other members of the copartnership and retains an inclividual interest in all or a part of the stock and ranches. Any subsequent transfer of his remaining interests affects the status of the copartnership as a permittee and generally is readily determinable. An individual permittee who transfer's to an incorporated company makes a complete transfer, retaining no interest in the stock or ranches, but receiving instear an interest in the corporation through the medium of certain shares or certificates which are readily transforrable, but which do not affect the status of the corporation as a permittee by their transfer. In renewal of permit to a copartnership only the proportionate interest transferred will be reduced in accordance with the rules governing the renewal of permits to purchasers, but in renewal of permit to a corporation the reduction will apply to the full number of stock 
transferred, even though the original permittee acquires and retains an interest in the corporation equivalent to his original interest in the stock grazed under his individual permit.

In the renewal of a permit held by a partnership to the individual

\section{Division of outfits.}

members, the same reductions will be made on the total number of stock grazed the previous year as would have been made on the original permit, each renewed permit bearing its pro rat a share of such reduction. The stockholders of a corporation which has dissolved may be allowed a renewal of permit under the rules governing renewal of permits to purchasers.

No division will be allowed when the number covered by the original permit is less than the protective limit. In case the number exceeds the protective limit, a division may be allowed, providerl that not more than one new owner secures a permit for less than the protective limit number of stock.

Partnership ordinarily means joint ownership of the stock and Dissolution of ranches, and the renewal to each member depends partnership. upon the division of each that is made. Signed agreements showing this division may be required by the Supervisor.

A renewal on the division of stock and ranches may give a member preference in the range for a certain number of stock, hut it does not define lis status or whether he is in class A, B, or C.

In order to prevent speculation, when a Forest is fully stocked, Renewals to pur- renewal of permit will not he allowed a purchaser of chasers. $\quad$ permitted stock if the original permittee has used the range less than three years. This rule will also apply when the permittee who proposes to sell is a member of a partnership.

If a permittee is bought out by several purchasers, division of the privileges among them will not be allowerl when the number of stock is less than the protective limit. In case the number exceeds the protective limit, division may be made if not more than one new owner is allowed a renewal of permit for less than the protective limit.

All permits issued to purchasers of permitted stock are subject to any reductions that would have been made in the original permit.

When stock is sold after the application for a grazing permit has been approved and prior to the beginning of the grazines period, the application of the purchaser may be approved upon his merits, subject to the reductions governing the issue of permits to the purchasers of stock.

The mere purchase of stock will not entitle the purchaser to share Purchase of stock in the grazing privileges during the following year only. unless he is otherwise qualified.

When the purchiser already owns ranch property commensurate with and so located that it will be used in connection with the stock, a renewal of the permit may be allowed for not to exceel so per cent of the oricinal permit. Then the number purchased is less than the protective limit, no reduction will be made if the purchaser has the qualifications of a class 1 applicant.

This reduction prevents speculation in National Forest rangre, and provides for new applicants.

When both the stock and ranches are purchased, a renewal may Purchase of stock be allowed the purchaser with any reduction that and ranches. woukl have been made in the original permit. 
If, after the transaction, the purchaser possesses all the qualifications of the original permittee he should be allowed the same privileges if the number of stock does not exceed the maximum limit. If he does not, the privilege should be reduced accordingly.

When a permittee in a fully stocked Forest sells the ranch property used in connection with his permit to a purchaser who

Purchase of ranches desires to secure a permit for other stock and sells
only. only.

his stock elsewhere, the purchaser of the ranch will be given a preference over other new owners or beginners, provided that the oriminal permittee rehinquishes his claim to renewal. In other words, the only preference secured by the purchase of a ranch without the stock is to liead the list of new beginners.

The factors which govern this ruling are, first, the original applicant must sign a waiver (Form 763) of renewal privileges; second, the purchaser of the ranch property must possess all of the class $A$ qualifications. (See instructions mider "Preferences," p. 35.)

Applications will be numbered when they are approved. DisProcedure. approved applications will not be numbered, but filed alphabetically under separate guide cards.
Cattle and horse permits and sheep and goat permits will be numbered separately. Mules, burros, and swine will be Numberng of ap- included with the cattle and horse series. The cattle plications. and horse series will begin each season with No. 1 and the sheep and goats with an arbitrary number, as 301, or 501, which will be above the highest number in the cattle and horse series. Where term permits are authorized, the cattle and horse term permits will be numbered consecutively, beginning with No. 1, and the annual permits numbered separately, beginning with a considerably higher number than any term permit. The sheep and goat series will be numbered similarly, the first number of the term permits being 301 or 501 , as the case may be, and of the annual permits being 601 or 801 , as the case may be.

Amended applications received before the issue of the permit will be given the same number as the original. One received afterwards will be given the same number as the original with the addition of the letters $a, b$, etc. An amended permit will be recorded on the original card, but supplemental permit requires a new card. If a term permittee desires an increase, which can properly be granted, a new application should be marle and the increase provided for by an annual permit.

If, however, the term permittee desires to decrease the number of stock, a new term permit may be issued.

The Supervisor will immediately notify the applicant of the approval of his application by a letter of transmittal Method of ap- (Form 861-G) showing the number of stock for
proval. which the application has been approved, the period and the fees to be paid. Any unusual conditions may be noted on the form. Whenever an amentment or a correction is made, or a supplemental application is approved, the notice will be marked "Amended," "Corrected," or "Supplemental," etc. A duplicate of each Form 861-G issued will be sent to the District Forester at once and a triplicate filed in the Supervisor's office.

Form 861-G for term permits will designate the year for which payment is to be made, thus: "Five-year period, first year." 
As duplicate notices of approval are received in the District District office. office they will be examined, and filed alphabetically under Forest guiles.

The District Forester will require such check to be made of grazing receipts as is necessary for a proper audit.

When a grazing application is disapproved, the Supervisor will notify the applicant by letter, giving the reasons for

Method of disap- his action and will send a copy of the letter to the
approval. approval. District Forester. The letter must furnish the applicant with adequate and conchusive reasons for the disapproval of his application, while the carbon furnishes the District Forester with the same information. It must assure both the applicant and the District Forester that the application has received proper consideration.

Upon receipt of notice that the applicant does not intend to pay the lees or accept the permit, or if for any reason the perMethod of cancel- mit is not issued afterwards, the Supervisor will close Iation. the case and mark the card " Canceled." The same serial number will not be used in any other case. Where necessary, the applicant will be informed at once of the action taken and the reasons for it, and a copy of the letter will be forwarded to the District Forester.

A recort card for each approved annual application will be made card record. on Form 621. 'Term permits will be recorded on Form 256 and the card transferred to the current files at the end of the grazing year. Cards will be filed alphabetically. The date of the Fiscal Agent's receipt, the amount of fee paid, and the late the permit is issued will be entered upon the card. When a refund is made the date of the voucher and the amount refunded will be noted upon the card. The back of the carl may bo used for a record of special matters.

When necessary, the Supervisor will notify all persons who have Delinquents. not paid the fees that their payments are overdue. Thirty days after the beginning of the grazing period the Supervisor will take such action as is justified in the case of each delinquent.

$86104^{\circ}-11-1$ 
SETTLEMENT OF CONTROVERSIES. (Reg. G-14.)

An appeal to the District Forester should be prepared in accordance with the instructions governing the preparation of appeals. (See "Appeals," p. 51). It should be filed in duplicate with the Supervisor, who will at once transmit one copy to the other party, with notice that 10 days from its receipt are allowed for answer. The answer should be in duplicate and should contain the statement of material facts required by the procedure under "Appeals," page 51. One copy will be transmitted to the original appellant, who will be allowed 10 days to make his final reply. All statements of appellants will be in writing and verified by oath, and may be accompanied by affidavits of witnesses. The originals of these papers will then be forwarded to the District Forester, and no other evidence will be taken unless called for by him. A copy of the Supervisor's decision in the case will, of course, accompany the appeal papers. Pending decision the party occupying the range will be allowed to continue its use, but must remove his stock within 10 days after receiving notice that the District Forester has decided against him, unless an appeal be taken to the Forester or the Secretary of Agriculture. In case of such an appeal the person in possession of the range will be allowed to continue its use until a final decision has been rendered.

In. case the appeal involves the use of a range where an advisory board has been recognized, copies of the appeal and answers may be referred to the advisory board with a request for a written opinion. 
APPEALS. (Reg. G-15.)

Upon receipt of request for a reconsideration of a case, the Supervisor will furnish the applicant with a copy of the Supervisor's decision. grazing regulations and of the instructions upon
Reconsideration. Reconsideration. which he based his decision, upon receipt of which the applicant will prepare his formal statement in writing, verify it by oatll, and accompany it by allidavits of available witnesses. This statement when submitted to the Supervisor will cover:

Actual and legal residence of applicant.

Period of residence.

Description and location of legal subdivisions of ranch property owned by applicant.

Character of ranch property owned by applicant.

(a) Improved farm land producing cultivated crops.

(b) Amount of summer pasture or range.

(c) Amount of winter pasture or range.

(d) Amount of land controlling water supply.

(e) Amount of forage produced annually.

Period of ownership.

Description of ranges upon which the stock was actually grazed during each of the years previously mentioned.

Number of years applicant has held a permit to graze stock on National Forest range.

Number of each class of stock grazed under permit during preceding year.

Number of each class of stock fed during each winter.

Quantity of forage fed during each winter.

Statement of reasons for reconsideration, citing the regulations and special instructions contrary to the Supervisor's decision.

List of witnesses who can substantiate the preceding statements.

List of affidarits submitted in eorroboration of statements.

And such other material facts as may have a bearing upon the case at issuc.

When all the evidence in the case has been filed by the applieant with the Supervisor, he will examine the record carefully, and if evidence upon material points is lacking he will notify the applicant of the omission and advise him that he will be given 10 days additional in which to submit the missing evidenec. Within 10 days from the date of the filing of the completed record the Supervisur will prepare a formal decision, discussing each point of the applicant's statement, and stating clearly the regulations and reasons upon which his decision is based. This will be forwarded by registered mail to the applicant.

Should the decision be adverse, the applicant may file written notice with the Supervisor within 10 days from the receipt of the registered decision, requesting a further considcration of material new evidence. 'The applicant will be advised by registered letter of the 
action taken upon his request, and if it is granted, will submit the additional evidence within the time set by the Supervisor. If the request is allowed, the Supervisor will prepare a final decision, which will be transmitted to the appellant in a registered letter If the request is refused, or if the Supervisor's final decision is adverse, the applicant may appeal to the District Forester by filing written notice with the Forest Supervisor within 10 days from the receipt of the registered notification. In an appeal before the District Forester, the appellant and the Forest Supervisor may each file an aroument or brief reviewing the previous decisions and the evidence in the ease. New evidence will not be admitted unless the applicant's request for the consideration of new evidence had been rejected by the Supervisor, in which event the new evidence may be submitted to the District Forester, and if material, will be considered by him.

When an appeal is taken to the District Forester the Supervisor will forward the complete record in the case to him Appeals to the Dis- for lis consideration. When this is received the trict Forester. $\quad$ District Forester will review it and prepare a decision, which will then be sent by registered mail to the appellant, and a copy transmitted to the Supervisor.

'The Supervisor's decision will not be reversed unless it is shown to be unwarranted by the facts, the regulations, instructions, or the law. When there is a variation in the statements of the Supervisor and the appellant, but the preponderance of the evidence shows the Supervisor to be justified in his action, he will be sustained.

Within 10 days from the receipt of the District Forester's decision, an appeal to the Forester may be filed with the District Forester.

Where a case is appealed to the Forester the appellant may file Appeals to the one additional statement, reviewing the previous Forester. decisions and presenting the argument. The District Forester will also file a statement. These two briefs, together with all papers in the case, will be presented to the Forester, and upon them his decision will be rendered.

Appeals may also be taken to the Secretary of Agriculture from adverse decisions of the Forester. Any party availing himself of this privilege must, within 30 days from the time he receives notice of the Forester's decision, file with the Forester his petition for review by the Secretary of Arriculture. Upon receipt of the petition the Forester will submit all the papers to the Secretary.

A field investigation of an appeal case may be ordered by the District Forester, the Forester, or the Secretary of Agriculture. The field examiner will submit a report which will be considered at the time the decision is rendered.

Copies of answers or reports will be furnished the appellant in the Examination of discretion of the deciding ollicer. 'The appellant or records.

his authorized agent may inspect the record of the case in the office of the Supervisor, District Forester, Forester, or Secretary of Agriculture, but will not be allowed to remove any papers. Statements of witnesses which have been submitted can not be regarded as confidential if they are considered as testimony. The appellant should be given full knowledge of the nuterial facts contained in such statements, and of the identity of the witnesses. Statements submitted in confidence and which must be treated as confidential can not be used as the basis for a decision. 
Upon receipt of a complaint in the District office, the District complants. Forester will determine whether the information in the files indicates that the Supervisor's action should be upheld. If so, the complainant will be informed in writing that the Supervisor's handling of the case was correct. If not, the information will be securerl, by field investigation if necessary, and the Supervisor given instructions. Tnless clearly in conflict with instructions and only where prompt action is necessary to prevent hardship, the Supervisor's artion will not be reversed on the basis of the record in the files when the complaint is received. 
BONDS. (Reg. G-16.)

The Supervisor may require the owners of stock to give bond to insure parment for damage caused by violation of the terms of the permit. "The amount of the bond will be determined by the Supervisor.

Ordinarily it will be for not less than twice or more than four times the amount of the grazing fee, or an amount which represents approximately the actual value of the forage.

A bond may be required of a former trespasser preliminary to the issuance of a permit, or of a permittee who has, during two successive seasons, disregarded the regulations, or whose employees are inclined to violate the regulations or disregard the orders of the Forest oflicers.

'The Supervisor will prepare the bond on Form 377, stating the number and kind of stock, describing the range, and stipulating that the stock will graze only on the area described. After approval by the District assistant to tha Solicitor, he will send it to the applicant with the notice of approval of his application for execution. . L pon its return the Supervisor will approve it if he is satisfied with the sureties. The permit will not be issued unt il the hond is approved.

All bonds required in connection with grazing permits will be filed in the Supervisor's oflice.

\section{PERMITS NOT TRANSFERABLE. (Reg. G-17.)}

In case a permittee sells stock under permit and the purchaser wishes to continue to graze it on the National Forest, New permits to upon presentation to the Supervisor of evidence that
purchasers. purchasers. the sale is bona fide the original permit will be canceled and a new permit issued to the purchaser without charge for the remaindel of the season. Such a permit will be given a new number in the regular serial oreler. If only a portion of the stock is sold, an amended permit for the number of stock retained will be issued to the original permittee and given the same number. No transfel of fees on the record is necessary in such cases. (For conditions roverning the renewal of such pernits the following season, see "Renewals of permits," p. 4s.)

Cross-reference entries will be made on the record

Cross reference. cards in cases of purchase. 


\section{ON AND OFF PERMITS. (Reg. G-18.)}

In the approval of applications from the owners of cattle and horses whrch graze on and off the National Forest an estimate will be made of the average number which will be grazed upon the Forest, and the fee will be paid upon this number.

On and off permits for sheep or goats may be issued for portions of the range along the Forest boundary not sufficient in area to support a band of sheep or goats during an entire established grazing period, which can only be utilized in connection with the adjoining outside range. Where portions of the outside range can only be used to advantage in connection with watering places located within the National Forests, on and off sheep or goat permits may be issued.

Sometimes the ownership of private land within a National Forest is unknown, or the owner does not object to its use On and off private without compensation or lease. In such cases per-
lands. mits may be issued for the adjoining range under the provisions of this Regulation and the grazing fees paid only on the stock which will be grazed upon National Forest land, but the permittee must agree to remove all stoek in excess of the number covered by the grazing permit if deprived of the use of the private lands by the owners or lessees thereof.

In issuing this elass of permit the grazing fees will be based on the grazing capacity of that portion of the range which is National Forest land.

The permit will be issued and the fees paid only for the number of animals which it is estimated will use Forest range during the season, but it will mention in a proviso the full number of animals which will be grazed both on and off the Forest. Only the number of animals upon which the fees are charged will be counted against the number authorized by the Secretary of Agriculture. 


\section{PRIVATE LANDS. (Reg. G-19.)}

Permits to cross a National Forest with stock which will be kept upon private lands, the owners or lessees of which do not desire to waive the right to its exclusive use, will be issued under the provisions of Reg. G-20.

The privilege of grazing sheep and goats upon National Forest lands, under this Regulation, will be allowed only upon such ranges as are open to this kind of stock.

The waiver of exclusive use of unfenced private land s not necessary where more than one-half of the land comprising the range is controlled by the applicant except when the interests of the Government demand it.

Before issuing permits under this Regulation the Supervisor must determine that the title of the land has passed from

Determination of the United States and that the applicant has the right status. to its use.

The following rules will govern grazing allowances on account of private land within the exterior limits of National Allowances for pri- Forests when it is desired to allow the use of National Forest lands upon a wairer by the owner of the private land to exclusive use thereof in favor of Forest Service permittees:

Bona fide settlers who have made homestead entry, but have not yet made final proof, may be allowed free permits for Unperfected en- grazing upon National Forest lands the number of
tries. animals their lands will support.

Persons who have filed upon land within the National Forests under laws not requiring residence may be allowed free permits for grazing upon National Forests the number of stock their lands will support, after they have made final payment for the land.

Owner's or lessees of Indian allotments may be allowed permits for grazing upon National Forests the number of animals

Indan allotments. the land will support, provided that patent has issued or a lease has been executed upon the blanks of the Indian Office and approved by the Commissioner of Indian Affairs.

Persons holding unpatented mining claims within a National Forest have the right to the grass or other forage upon such

Mining claims. claim needed for stock used in connection with the development of the claims, but they have no right to dispose of the forage to any other person or to collect rental for the use of the claims for grazing purposes. Such unperfected mining claims therefore can not be accepted as the basis for a permit under this Regulation.

Persons holding permits for range within which mining claims occur should be warned not to allow their stock to graze upon them without the consent of the claimant. 
Bona ficle squatters upon unsurveyed lands may be allowed permits Squatters' claims.

for grazing the number of animals their claims will support, provided no claim exceeds 160 acres. No conflicting claims will be recognized until the matter has been determined by the Department of the Interior.

Persons who have applied to purchase or who have leased any lands covered by State sclections will not be allowed free grazing privileges on account of these lands until the State selections. lists have been approved by the Commissioner of the General Land Office.

Persons who have applied to purchase or who have leased railroad Rallroad land. land within the indemnity limits will be allowed free grazing privileges on account of such land after survey and selection by the railroad company and approval by the Secretary of the Interior.

The use of unsurvered, unselected lands within the indemnity limits of railroad grants will be allowed in accordance with the grazing regulations under regular paid permits.

In every possible instance the grazing capacity of the lands offered Determination of as the basis of the free permit should be determined by rangecapacity. field examination and reported upon Form 251.

When an application for a permit in exchange for the use of private Procedure. lands is received, card record (Form 403) will be made showing the name and address of the applicant, the acreage of the land owned or leased, the number of each kind ol stock to be grazed, the location of the range to be oceupied, and the grazing period. The cards will be filed alphabetically behind the record cards for the regular paid permits.

The application (Form 925), report on the grazing capacity of the land (Form 251), and the duplicate copy of the permit (Form 256) will be placed in a folder and designated according to instructions. The permit will be written in triplicate, the original sent the applicant, the duplicate filed, and the triplicate sent to the ranger in charge of the district. 


\section{CROSSING PERMITS. (Reg. G-20.)}

Crossing permits may be granted for crossing stock orer National Forest lands to points beyond the National Forest; for crossing stock to private lands within a National Forest, or for crossing stock to reach dipping vats or railroad shipping points.

Applications for crossing permits may be made either in person or Applications. by letter, and the permits issued to either the owner or person in charge of the stock.

Crossing permits will be issued in triplicate (Form S74-17), one Permits. copy delivered to the applicant, one copy retained by the issuing officer, and one copy sent the Supervisor. Crossing permits will not be issued prior to the opening of the When denied grazing season for the class of stock concerned, except upon an established driveway. They will not be issued for stork which is so poor that it will not be able to cross the Forest, and they will not be issued for stoek to be driven to private land within the Forest if the land is unfenced and the number of stock is greater than it will support without trespass upon adjoining Forest lands. Of course, it is not reasonable to refuse a crossing permit for this reason before the grazing capacity of theland has been determinet.

When stock is to be driven across more than one Forest, it should Interforest per- not be allowed to enter the first Forest until erossing mits.

permits have been obtained for the others.

However, where customary routes of travel or stock driveways cross two or more adjoining Forests, interforest crossing permits may be issued under an agreement between the Supervisors. 'The permit will be issued on the Forest which the stock first enter, and will grant the privilege of crossing all of the Forest land traversed by the driveway. Copies of interforest crossing permits will be forwarded to all Supervisors concerned.

The dates between which the permit may be used should include a Period effective. period sufficient to provide against unavoidable delay.

To illustrate, where the time required to cross a Forest is 4 days, the permit may bo made effective for 15 days, with a proviso that not more than 4 days will be used in crossing.

If occasion demands, rangers will accompany the stock and see that supervision. there is no delay or trespassing.

No charge will be made for crossing permits issued under this regulation. When a permit is desired for crossing the Forest with stock Pald permits. at regular intervals during an entire grazing season, or under other conditions which warrant the charging of a grazing fee, the grazing permit will be issued under Regulation $\mathrm{G}-5$ and included in the regular numbered series.

If the Forest includes a shipping point or if it must be crossed to reach one by nonpermittees trailing stock and limited grazing is necessary to prevent shrinkage, the Forester may authorize a grazing 
period of 10, 20, or 30 days, as the case may be, at a specified charge per band of sheep or cattle for the period established. The charge in such cases will be based upon the entire period and no allowance will be made if the range is used for a shorter time.

It is absolutely essential that persons crossing stock comply with the regulations governing the National Forests and Quarantine regu- with the quarantine regulations prescribed by the
atlons. Secretary of Agriculture and the State authorities. Unless they do so the privilege may be denied them, but the comlition of stock as to contagious or infections diseases will be deternined by the proper Frderal or State authorities. Compliance being assured, and if the privilege will not expose the National Forest to damage or the regular permittees using it to inconvenience or financial loss, the permit should be issued without delay and with the fewest possible restrictions.

Before issuing a permit to reach private land, the Forest officer may Crossing to private require a written statement of ownership of the land lands. or a copy of the lease thereof.

If the land is uninclosed and the applicant does not desire to waive the right to its exclusive use, the stock must be so handled that the animals will not intrude upon adjoining Forest areas. In order to protect the Forest from trespass or injury, an application for crossing with more stock than the land will support nay be denied.

When the private land is securely fenced, the pernit may be allowed for any number of stock the applicant desires to graze upon his land.

It is inadrisable to allow umpermitted sheep to cross National Crossing to dip- Forest lants to be dipped at a vat within the Forest, ping vats or shipping unless there is no arailable dipping rat outside of the
points. limits of the Forest, but the Forest Service will not prevent compliance with the Federal or State quarantine requirements by refusing aceess to a dipping' vat so located. 'The Supervisor will determine for each vat on his Forest whether the circumstances warrant the granting of this privilege, and the restrictions which should govern it and will instruct the rangers accordingly.

If a shipping point within a National Forest is the only one reasonably aceessible to persons grazing stock outside, the Supervisor may allow crossing privileges under such restrictions as are necessary to protect the interests of regular permittees.

The regular grazing permit carries with it the right to drive the Crossing to per- stock over National Forest lands to and from the mitted ranges. scason, and from the range to the most accessible shearing, dipping, and shipping points during the term of the permit. Supervisors should require permittees to secure adelitional crossing permits only when it is clearly eviclent that the unrestricted privilege is detrimental to the Forest or to other permittees. 
The primary purpose of all the regulations is to make the National Forests as useful als possible to the people, consistent with their protection and perpetuation. It is evident that a committee selected by an organized body of representative users is capable of giving extremely valuable advice upon the handling of the interests represented. It is clearly impossible to meet the wishes of each individual user, but it may be entirely possible to meet the wishes of the majority made known through an organization. It is to sectire from the people collectively definite statements of their needs and wishes that the organization of stock associations is encouraged.

Live-stock associations desiring to take adrantage of this regulation

How formed. must file an application with the Supervisor, giving the names of all members, the name of the Forest in which its members are interested, and the names of the committeemen who are to act for the association. The advisory board must consist of not more than five members, who must be users of the National Forest, and a majority of the board must constitute a quorum.

The application must be accompanied by a copy of the constitution and hy-laws and a statement that the action of the board will be binding upon the association. These by-laws must provide that all persons who are permitted to graze the kind of stock represented by the association will be eligil,le to membership.

After having examined the application the Supervisor will forward Procedure. it to the District Forester accompanied by a copy of the constitution and by-laws. He will state whether or not the membership comprises a majority of the permittees for the particular class or classes of stock within the Forest or grazing district for which recognition is requested, and make a recommendation for or against its approval. Upon approval by the District Forester, the association will be notified and entitled to the recognition under this regulation. The letter of notification will be sent the secretary of the association and copies sent the Forester and Supervisor, on receipt of which the Supervisor will arrange for cooperation with the association. Applications for recognition of advisory boards not submitted through the Supervisor will be referred to him for recommendation.

$A$ card record of recognized stock associations will be kept. The

Card record. title of the association, names and addresses of its officers and the members of the advisory board, and the grazing district or Forest for which recognition is granted will be entered on a card which will be filed by Forests. A copy of each card will be sent the Forester, who will be kept informed of changes.

Supervisors should inform the District Forester of any change in the personnel of advisory boards or amendments in the constitution or bylaws adopted by recognized stock associations. 
If the application is disapproved by the District Forester, the secretary of the association will be informed and specific Disapproved appli- reasons given. On receipt of a copy of such a letter,
cations.

the Supervisor may take the nuatter up with the local representatives, show them what is necessary to correct their application or enlarge their organization to seeure recognition. Disapproval for noneompliance with this regulation need not preclude reapplication and subsequent approval. An appeal from the District Forester's refusal to recognize a stock association may be made to the Forester.

While the Forest Service must control the grazing on the Forests and retain the administrative authority, it must be Action on recom- remembered that an advisory board is in a position
mendations. ing the association.

to express accurately the wants of stockmen compos-

It is the responsibility of the Forest officer to determine in each instance whether the wants of the people are compatible with the good of the Forest. When they are not, the latter will govern.

When it is necessary to disapprove the reconmendations of an advisory board the Supervisor will furnish them a clear statement of his reasons for such disapproval.

The advisory board may, if the Supervisor's action and reasons are Appeals by ad- unsatisfactory, appeal to the District Forester and visory boards. from his decision to the Forester, and from the Forester's decision to the Secretary of Agriculture.

State associations may appoint advisory boards for any Forest in state associations. the State in which their membership includes a majority of the users. A single advisory board representing a State association may be consulted by the District Forester on questions which concern the entire State.

If, after setting any date of meeting with an advisory board giving Meetings. ample time for all members to attend either in person or by proxy, a majority of the board is not present, the Supervisor or District Forester will be relieved from all obligation to delay action or confer with the board.

National live-stock associations representing the owners of any kind of stock using the National Forests, may appoint an National associa- advisory board, which will be recognized by the Secre-
tions. tary of Agriculture and consulted with annually at such tinie and place as may be agreed upon in reference to matters affecting the use of all of the National Forests.

Complaint against the Supervisor's action by members of the assoComplaints of ciation should be taken up through the advisory board members. direct as an individual.

Where there is more than one advisory board on a Forest, care

Area covered. should be taken to see that the members understand clearly the boundaries of the area over which their jurisdiction extends, whether it be a Forest, a grazing district, or a few divisions. In handling important range questions which it is necessary to refer to an advisory board complications may be avoided by having this thoroughly understood beforehand.

Matters submitted to advisory boards should be of general rather than individual or personal interest. An individual case, however, 
may contain a principle in which a large number of permittees are interested, in which event it may very properly be taken up.

The Supervisor of the Forest concerned or one delegate selected by him, upon receipt of an authorized request, may Attendance at attend, without receiving specific authority from the meetings.

Secretary of Agriculture, any meeting of the stockmen using the Forest or of an association of which they are members, at which his presence will tend to facilitate the administration of the Forest or will be of mutual benefit to the Forest Service and the users of the National Forest. 


\section{COUNTING STOCK. (Reg. G-22.)}

Counting corrals should be constructed at convenient points to facilitate compliance with this Regulation and an actual count will be made wherever possible, without serious interference with the proper handling of the stock. Slight disclepancies may be permitted from the number covered by permit when an exact count is impossible. When it is, a very slight exeess in a large permit may he overlooked or a supplemental application for the excess required. When the excess is so great as to warrant the assmmption than an attempt is being male to avoid parment of fees, the excess number may be denied entrance to the Forest. A report on stock counted (Form 874-1S) will be sent to the Supervisor as soon as practicable.

Where the local Forest officers are in possession of reliable information that the number of stock being brought in by a permittee is not in excess of his permit number, counting may be lispensed with, especially if it involves a matcrial expense to the Scrvice.

Sheep can be easily counted where there is a corral or where a

counting sheep. wing can be readily constructed, and therefore should be counted each season as they enter the Forest or shortly afterwards.

Ordinarily an excess of 10 head per thousand may be ignored. If the range is heavily stocked any greater excess should be removed from the herd before it is allowed to enter. If the range is not heavily stocked, the excess number may be allowed to remain in the herd if the owner will immediately apply for a supplemental permit for the whole excess.

Where cattle or horses are driven to Forest ranges from the feed lots or winter ranges, a count may be made at points

Counting cattle of entry designated by the Forest officers. In many and horses. instances, however, the stock is either ruming loose or turned loose in the spring and naturally drifts onto the National Forest ranges. There yearlong ranges are included the stock may never leave the Forest and selfom be rounded up.

In such cases the number of cattle or horses being grazed upon a National Forest range may be apploximately determined in several ways. Stock may be counted in the feed lots where winter feeling is the rule, a count may be secured in a round-up, or close estimates may be made on the basis of range counts, branding tallies, or sales.

Counting in the feed lots can be clone at a time when it will interfere

Feed lot counts. little with a ranger's duties. 'The results are faily accurate. If the number for which application is submitted is less than the number in the possession of the applicant at the time the count was made he may be required on entering the Forest to show what disposition has been made of the balance. An applicant who refuses to allow his stock to be counted in a feed lot may be required to arrange for a count before entering the Forest or to round-up at any time thereafter if the Supervisol has reason to believe that the number being grazed is in excess of the permitted number. 
I count of a permittee's cattle on the range is a difficult and Round-ups. expensive matter. Where the cattle are wild and used to being rounded up only at stated periods, this action must be done with all possible regard for the stockmen as well as the Forest. An unusual round-up costs money, causcs a loss in the value of the stock, drifting from their ranges, and umnecessary damage to the range. Consequently such round-up counts should be avoided unless absolutely necessary and wherever possible the number ascertained by other methods.

Regular beef, calf, or stock round-ups inaugurated by the storkmen themselves should in no way be under the control of the Forest Service. Every Forest officer should avoid arbitrary action in business matters of this kind, except when it is necessary in order to protect the interests of the Forest. Unless the force of Forest officers is sufficient to be with each party of riders all day or unless they have the full cooperation of the stockmen an accurate count of each permittce's stock can not be expected, but luckily the latter is often the case.

Forest officers detailed to accompany a round-up will give first attention to their work which is to determine the numbers of permitted stock. They should, howerer, help the stockmen where they can and avoid an unnecessary disregard of the authority of the person in charge of the work.

Under ordinary conditions of stock raising, four times the number

Calf tally. of calves branded in an average year will approximate the total number of stock the owner has, from ycarlings up. To illustrate, if a man brands 100 calves in a normal season it is probable that he has about 400 head of cattle, counting yearlings and beef on the range. The calf tally nultiplied by 5 will give the approximate number of stock the owricr will have on the range in the following year less the number of head sold or lost.

The record of stock sold and slaughtered, which usually may be

Sales records. obtained from the State Sanitary Board and checked up by railroad records when the stock is shipped from railroad points, will furnish a close approximation of the number of stock a permittee is grazing provided he is not selling steers raised by other users of the range.

An estimate based upon the stock found upon a certain range

Range estimates. is of little value unless it is made by two or more men simultaneously to make sure the same animals were not counted twice. A single ranger should not attempt a range count that will extend over more than one day unless he is certain that stock seen the first day will not stray upon the area to be worked the second.

Some animals are bound to be overlooked in a range count, thercfore the estimate should be based upon the assumed ratio of the cattle seen and counted to the cattle on the range. This percentage will rarely be more than two-thirds, and may be half. If the count is based on the work of several men, it is possible to apply as a check the percentage of the calf crop that was overlooked on the round-up and subsequently range branded, but this of course is a suggestion only.

The owners of stock which is kept under herd upon the National Forests will be furnished with cards (Form 976) for the identificatiou of their herders by Forest officers. 
DAMAGE BY STOCK. (Reg. G-23.)

Stockmen may and should be required to repair all clamage caused by the presence of their stock upon the Forest, but sliould not be called upon to make the repairs of damage not caused by their stock. It is entirely reasonable to require a permittee to clear a road or trail which has been filled with rocks by the passage of his stock, but it is not reasonable to ask lim to repair roads or trails that were in poor condition before his stock entered the Forest. It is also reasonable to require the feneing and troughing of a spring or seep which has been damagerl by the stork of a permittee. Otherwise the Service should undertake the improvement with the cooperation of the interested permittees if they can be persuaded to assist.

\section{BEDDING SHEEP AND GOATS. (Reg. G-24.)}

The prolonged use of one bed ground by a band of sheep is Bedgrounds. destructive to the range because the amount of forage tramped by a close herded band of sheep is t as the amount actually fed. Then, too, the sheep leave the bed ground hungry and eat a large number of plants in the vicinity of the bed ground that ordinarily would escape destruction. Reestablishment of the forage thus destroved is difficult if not impossible. To reduce the damage to a minimum the bed ground should be changed every six days at least. Lambing ewes can not be moved every six days, and the interests of the rango must in this instance be sacificed in a measure to the needs of the shecp. Where no such exigeney exists, and where the Government is not compensated for the damage (by the lambing (harge), sheep must not be allowed to occupy one bed ground for more than six days.

The bedding of sheep within 300 rards of a stream or spring that is a source of water supply for a community or town must not be allowed under any circumstances.

\section{DISPOSITION OF CARCASSES. (Reg. G-25.)}

To prevent the pollution of water supply and the spread of disease among human beings, as well as live stock, this mule will be strictly enforced. The carcasses of animals dying from blackleg, anthrax, glanders, and other bacterial diseases scatter germs on the range when they decompose, and a healthy animal may contract the disease. Therefore range losses will be materially reduced if all carcasses are burned. 


\section{SALTING STOCK. (Reg. G-26.)}

Sheep will consume about a pound and a half of salt during a summer season. Deprived of salt they are harder to herd and more destructive to the range.

Cattle and horses will use approximately 2 pounds of salt per head per month from the time the green feed begins until midsummer and 1 pound per head per month during the remainder of the year. This quantity is in excess of that fed on most ranges, but experience has demonstrated that a liberal use of salt is a profitable investment. A lack of salt causes cattle to collect around old salt grounds and tramp out considerable range.

Salting is required as a means of Forest protection, and the regulation should be enfored to as great an extent as the interests of the Forest demand. Otherwise it should be enforced only upon the request of a majority of the permittees or when the State laws require the salting of stock.

Ordinarily a person who refuses, upon request, to salt lis stock will be subject to a reduction in permit number churing the following year. If his disregard is continued, and results in damage to the range, lie may be denied further privileges. Obviously, where natural licks occur salting will be unnecessary.

Salt and water are two important factors in distributing cattle and horses on the range. Stock will alternate between salt and water if the two are widely separated, and will consume as much range around a salt ground as around a water liole. For this reason the best results are secured by placing the salt on rocky points at some distance away from the water. The salt licks or troughs sliould be placed on ground of no value for other purposes. 
Whenever the stock in any locality is known to be infected with a contagious disease, or notice to that effect has been given the Forester or District Forester by the Bureau of Animal Industry, the owners of all stock to be grazed in National Forests must, if required to do so, subject the stock to inspection, and, if found necessary, have such stock dipped or otherwise treated hefore it is allowed to enter. At any time during the period for which a grazing permit has been issued, if the stock is found to be infeeted with a contagious disease, it must he dipped or otherwise treated in aceordance with the instructions of the inspectors of the Bureau of Animal Industry, or the permit will be canceled and the stock removed from the National Forests.

The owners of all stock grazed under permit must comply with the live-stock laws of the State or Territory or their permits will be canceled. Rangers will report at once any violation of the live-stock laws and will assist the stock owners to protect their property against loss by theft.

Upon receipt from the Forester of a statement of quarantine or inspection work to be condueted by the Bureau of Animal Industry during the grazing season the District Forester will communicate with the Bureau of Anmal Industry District Inspectors, requesting information regarding the quarantine or inspection regulations to be in force during the season, and the Forests to which they will apply.

When this information is received the Supervisors concerned will be informed of the same and address of the district inspector in charge and will be instructed regarding the regulations to be in force and to cooperate with the officers of the Bureau of Animal Industry, rendering them the necessary assistance and furnishing them with a list of the permittees, the dates upon which the stock will enter the Forest, and all other information required.

The same routine will be followed in regard to State quarantine regulations, unless they conflict with the regulations of the Bureau of Animal Industry.

The enforeement of Fecleral or State quarantine regulations will not he undertaken by the Forest Service except in cooperation with the Bureau of Animal Industry or State official in charge, and Supervisors will in all cases be furnished with definite instructions for their guidance.

Upon receipt of requests for the enforcement of State or Federal quarantine regulations which conflict with Forest interests, or of requests from a State official which conflict with the regulations of the Bureau of Animal Industry, the District Forester will endeavor to secure a modification. If this can not be secured, the matter will be submitted to the Forester for decision before final instructions are issued to Supervisors.

Rangers should, when necessary, inform all persons of the local stock laws and endeavor to prevent their violation. If actual violation of 
the law is discovered by the ranger, he will at once notify the proper State officer, if practicable, and report this action to the Supervisor. If unable to communicate with the State officer, or if no action follows, he will give the facts to the Supervisor, who will transmit them to the proper State authority. Afl officers of the Forest Service will assist the proper State or Territorial officials in the enforcement of all quarantine and live-stock laws.

The scope of the regulations of the Secretary of Agriculture is limited to the protection, occupancy, and use of the National Forests. It is realized that certain restrictions in the use of the range, other than those prescribed for the protection, occupancy, or use of the National Forests, might improve range conditions and protect the majority of the stoek growers from losses by theft and the negligence of the minority, lut these matters are outside of the authority conf rred by the act of June 4, 1897. If they are covered by State or Territorial laws they may be remedied by the enforcement of such laws. If they are not, the Forest Service can take action, only when Forest interests are threatened.

Whenever it is found that the stock interests are suffering on account of the ravages of wolves, cougars, coyotes, bobeats, or other predatory animals, a report should be made to the District Forester, with recommendations for such action as is necessary to reduce their numbers.

Forest rangers and guards may be assigned to the work of hunting predatory animals for a limited time each year and will be furnished with necessary ammunition, poisons, and traps. If none are sufficiently experienced or can be spared for the work, professional hunters may be recommended by the Supervisor for appointment as guards for such period as their services are required. The Supervisor will check the progress and effect of each hunter's work by inspection and such periodic reports on Form 343 as he may require, and will initiate such action as is necessary for their transfer, furlough, or separation. The final results of the hunters' work will be reported to the District Forester in the annual statistical report (July 15).

Recommendations for the appointment of guards or rangers to serve as hunters will be referred to Grazing which will signify approvai of such appointments by a memorandum to Operation. 


\section{PROTECTION OF GAME, FISH, AND BIRDS. (Reg. G-28.)}

Wild game aclels materially to the enjoyment of the National value of game na Forests by the public. It is as clearly the duty of the Forest. Forest Service to do all in its power to protect game as it is to protect the National Forests.

While the authority for making laws restricting hunting and for the protection of game birds and animals outside Cooperation with National game refuges is rested in the State and
state authorities. state authorities. Territorial legislatures, it is expected that Forest officers will cooperate with the local authorities in the enforcement of these laws in every possible way. A passive cooperation which permits rangers to refuse appointments as deputy game wardens or to overlook infractions of the game laws will not be tolerated.

The District Forester will enclearor to arrange a definite plan of cooperation with the State or Territorial authorities.

Actioninitiated by He will offer the cooperation of the Forest Service District Forester. in the protection of game on the National Forests in the District, furnish lists of rangers whose appointment as deputy game warlen is desirable, and will assist in every proper way in the collection of eridence and the prosecution of offenders.

The Supervisor will see that the plan of cooperation is put into effect on the Forest. He will recommend, through Duties of Forest the District Forester, such of the rangers for appoint-
officers. ment as deputy game wardens as are necessary to protect adequately the game on the Forest. It is not intended that this work shall interfere with the regular Forest business, but it should be carried to the highest point of efliciency possible without such interference. Nor is it intended that Forest oflicers should enforce the game laws with any less tact and judgment than is required in the enforcement of National Forest regulations. Copies of the local game laws can always be obtained in sufficient quantities for distribution among campers and travelers, and courteous instruction in regard to them will usually save the disagreeable necessity of an arrest for their violation.

Forest oflicers are authorized to accept bounties offered and Fees and bounties. voluntarily paid by the State, counties, associations, or individuals for predatory animals killed, but must not accept any fees or parts of fines on account of enforcement of State game laws.

In making range allotments the Supervisor shoukl see that limited winter or summer feeling grounds, and in some Interference by live cases breeding grounds, of elk, deer, antelope, moun-
stock.

tain sheep, or mountain goat are not crowded with stock to the extent of driving the game from its natural range or of depriving it of winter feed upon which it is dependent. On adjoining Forests cooperation on the part of both Supervisors may be necessary to accomplish this. In other (ases, sheep may be excluded 
from limited areas to provide nesting places for game birds, such as pheasants, grouse, wild turkey, ptarmigan, or mountain quail. No arbitrary action should be taken which would cause hardship to stock owners. Wherever possible the owners affected should be consulted and incluced if possible to agree to the proposed action.

Forest guards and hunters appointed for the purpose of killing and trapping predatory animals may be assigned Assignment of For- to work in portions of the Forest where such animals
est hunters. are known to be killing game in quantities. Rangers should be instructed to report instances of game killed by predatory animals.

If the Supervisor liscovers that the number of game fish is matestocking streams. rially decreasing in a streams, or that good streams or lakes exist in which there are no fish, he may report the fact to the District Forester, who will take it up with the State authorities if they own or eontrol hatcheries, or through the Forester with the United States Bureau of Fisheries, with a view to having fry sent the Supervisor for stocking the waters of his Forest. Rare species in danger of extinction should be reported to the Forester for advice from the United States Bureau of Fisheries.

If the Supervisor finds that the local game laws are inadequate to protect the game or fish in his locality-for example, Inadequate or con- if the open season on deer allows hunting during the
flicting State laws. mating season or permits quail to be killed before the young are able to care for themselves-he should report to the Distriet Forester, who will bring it to the attention of the State warden.

When any class of game on a Forest is in danger of extermination, the Supervisor should investigate the matter as Game extermina- thoroughly as possible. If he considers that the emer-
tion. gency is serious or that peeuliar conditions exist, he will make a preliminary report to the Distriet Forester requesting the detail of a representative of the Biological Survey to his Forest to conduct further investigations. If the District Forester concurs, he will prepare a letter to the Chief of the Bureau of the Biological Survey for the signature of the Forester requesting this cooperation. 


\section{GAME AND BIRD REFUGES.}

Four different classes of game and bird refuges may be included Four classes. within the National Forests: National game refuges or areas in which the killing of game animals is prohibited by acts of Congress; National bird refuges or areas in which the killing of birds is prohibited by acts of Congress; State game preserves, or areas in which the killing of game is prohibited by the legislature of the State or 'Territorr; and protected areas or areas closed to the grazing of all classes of stock in order to protect game in its natural feeding or breeding grounds, but where hunting is allowed by the State laws.

National game refuges are created by specific acts of Congress for the purpose of preventing trespass upon public lands

Nationalgameref- in order to protect game and birds. Within a uges.

National game refuge local game laws apply only on private, State, or Territorial lands.

The hunting, trapping, capturing, or killing of game animals upon a National game refuge in violation of any of the Authority of regulations for their protection prescribed by the rangers.

Secretary of Agriculture under the authority of the statute creating it is a violation of the statute, and offencters will be tried in the Tnited States district courts and not in the State or 'Territorial courts. Under authority granted by Congress, rangers are empowered to arrest persons violating National game refuge regulations.

In making arrests Forest officers must be certain that the hunting,

Arrests. trapping, capturing, or killing of the game animals took place upon Government land within the limits of the National game refuge and not upon land in private, State, or 'Territorial ownership, and must be prepared to prove these facts before the United States commissioner and in subsequent court proceedings.

When a game warden is appointed from the United States Civil

Game wardens. Service list for a game preserve within a National Forest he may be designated as acting supervisor and be placed in charge of the Forest, but game wartens who are not placed in charge of a Forest will work under instructions from the Supervisor the same as other Forest oflicers.

National bird refuges have been created under authority of an act of Congress, by Executive proclamation or order.

National bird ref- The hunting, trapping, capturing, willfully disturbing,
uges. or killing any bird of any kind whatever or taking the eggs of such hirds on any lands of the United States within National bird refuges in violation of any of the regulations prescribed by the Secretary of Agriculture is a violation of the statute. Legal procelure and action on the part of Forest officers in cases of violation of the regulations on National bird refuges will be the same as on National game refuges. 
State game preserves are created by specific acts of the State or Territorial legislature for the purpose of protecting State game pre- game animals. Such acts apply to all lands embraced
serves. within the described area, including public lands of the United States, unless they conflict with acts of Congress. The kitling of game in violation of the act creating a State game preserve is a violation of the State or Territorial laws, and offenders will be tried in the State or Territorial courts. Forest officers have Authority of authority to arrest for violations of such laws only
rangers. after ther have been appointed State or 'Territorial game wardens, or have been given special authority by the State legislature.

When a State game preserve is established within a National Procedure. Forest, the District Forester will communicate with the State game warden, ofiering the cooperation of the Forest Service in the enforcement of any regulations for the protection of animals in the State Game Preserve. Cooperation with Upon receipt of a request from the State game State game warden. warden that any special action be taken, the necessary instructions will be issued to the Forest officers concerned.

If in the judgment of the District Forester it is contrary to the best interest of the Forest to comply with the State game warden's request, he may refer the matter to the Forester.

Protected areas may be established by the Forester within the

Protected areas. National Forests by the exclusion of live stock from limited areas which are the natural feeding or breeding grounds of game animals or birds. Since such areas must remain open to hunting under the State game law, an effort should be made to secure the cooperation of the State to prohibit the killing of game animals within protected areas.

The boundaries of protected areas should be plainly marked with notices showing that the areas are closed to the grazGrazing trespass ing of certain or all classes of stock. The grazing on protected areas. trespass. Forest officers having charge of districts within which there are protected areas will give them the most effective protection possible.

All matters dealing with the protection of game on National Forests will be handled in the District offices by officers designated by the District Forester and in Washington by officers designated by the Forester. 


\section{STRAY OR UNBRANDED STOCK.}

The ownership of all stray or unbranded stock upon the National Forests will be determined by the laws of the State or Territory in which the Forest is located, and Forest oflicers will be governed by such laws in the handling of stray or unbranded stock. Persons legally entitled to acquire title to stray or unbranded stock mav be allowed to do so, but no permit or agreement should be granted or entered into by any Forest officer which authorizes a charge to be made for the gathering of such stock or its sale by the person or persons who have gathered or captured it.

The owners of all branded animals which are captured with unbranded stock will be required to make application for permit and pay the grazing lees upon them. Stray or unbrancled stock, if not claimed ly persons entitled to it under the law, will be held, and the State or "Territorial suthorities requested to take charge of it or authorize the Forest oflicer to dispose of it in accorclance with the State or 'Territorial law.

Forest officers should not attempt to acquire title to stray or unbranded stock, or assume that its presence upon the Forest gires any right to its use, except when they are qualified under the law to acquire ownership of the stock.

The construction of corrals or pastures for use in capturing wild unbranded stock may be allowed under the rules governing other special uses of the National Forest.

Reimbursement for expenses incurred by Forest officels in the capture or removal of unbranded stock from the National Forests, in excess of their ordinary expenses, may be allowed when the expenditure has been anthorized by the District Forester. 


\section{METHODS OF RANGE IMPROVEMENT,}

Improvement of National Forest ranges may be effected in three ways:

1. Improved methods of handling stock.

2. Improvement of range by natural reseeding.

3. Improvement of range by artificial seeding.

Sheep.-By carcul experimental study it has been found that sheep ummolested in pasture require only from 65 to 80 per Better methods of cent as much lange as when herded in bands in the open.
handling the stock.

This is clue to the difference in the actions of the sheep. In pasture they wander about singly or in groups as cattle do, graze quictly, and bed in any opening where night overtakes them. Consequently, the forage is eatem instead of being destroyed, as it is on the range by close bunching, stampeding, and trailing back and forth to camp. The more nearly the former condition can be approached on National forests the better for the range as well as for the sheep. Herders should be induced, whererer possible, to a roil quick massing with dogs, to bed the band where night overtakes it, and to leave a camp in good condition and return to it later rather than feeding it out to its full capacity in one visit.

Cattle.-Cattle have a tentency to congregite and graze in areas in the neighborhood of watering plares and salt grounds. To offset this new water holes may be developed and salt at a distance from water distributed.

(roats.--There goat herlers maintain but one camp where the goats return to bed night alter night as is the custom, the entire range about the eamp is destroved. Not only the grass and forage but the shrubs and even small trees are killed.

Where goats graze upon National Forest ranges they will not be allowed for more than six successive nights upon one bed ground except during the kidding scason. If goat herders can be induced to handle their bands with a movable camp following the herd, the damage done could be greatly reduced and much of the objection to their presence on National Forests woukl be remored. The rapidity with which feeding goats move over a range is another injurious element. This may be prevented by the herder if he will hold the herd and force them to scatter and graze more openly.

One of the chief reasons for the slow recovery of impoverished Natural reseeding. ranges is the fact that the forage is usually grazed each year before the seed crop is mature. It has been found that a portion at least of each range can be protected until the seed of the most important forage species has matured and seattered with no serions inconvenience to the stockmen. The area that can be set aside for later grazing will depend upon the time at which the seed crop ripens. If, for example, one-fifth of the season remains 
after the seed has matured, one-fifth of the entire range allotment may be set aside for natural seeding each season.

After the seed has ripened the reserved area may be grazed in the usual manner in order that the seed may be tramped into the ground. It is advisable to make the same reservation the following year in order to give the seedlings a chance to develop a strong root system.

On ranges so severely overgrazed that the desirable forage species have been almost entirely destroyed and the lands are Artifial reseeding. henuded, it is evident that artificial reseeding must be resorted to. When such work is undertaken two points must be remembered in selecting speries for planting. First, the soil and moisture requirements of the plant itself, and second, the soil and chimatic conditions of the area to be seeded. Reltop for example, should never be sown in dry soils, or even on meadows which may become dry in the latter part of the season. Smooth brome grass, which is one of the most drought-resistant species known, would in all probability not succeed in a moist locality.

In reseedling with forage species which make a quick height growth

choice of areas. or a heary sod, care should be taken to insure against competition with the reproduction of tree species, where forest reproduction is possible. Therefore in such cases a species like orchard grass, which forms tussocks, may be userl. Such grasses leave a portion of the soil exposed where the tree seed may start.

The areas selected for seeding experiments need not be large. For a single species an acre, or even half an acre, is ample. It is essential, however, that the area selected should be representative of the general conditions on the range in need of reseeding. In order to obtain reliable results, experiments will necessarily extend over a period of years. To insure a fair test the experimental plot, or at least a portion of it, should be fenced. A detailed record of the work should be kept by the officer responsible for the experiment and progress reports submitted at the close of each growing season. The accompanying Blank $A$ will be filled ont when the experiment is started, and Blank B used for progress reports

Blank A.]

[To be made in duplicate.

REPORT ON

Grass Seeding Station.

National Forest.

Area.

Strip No.

(Designation on location post.)

Established $191 \ldots$

Location

(By section, township, and range, if possible.) 
Character of site:

Exposure.

Slope

\section{(Approximate degrees of incline.)}

Altitude

Soil type

(Sandy, clay loam, gravelly loam, etc.)

Cover

(Trees, brush, grass-stating only most ahundant species.)

Past history

(cut over, grazed, burned-state when burning took place, if possible.)

Protection.

(Fenced or mesely protected by herding.)

Moisture.

(Submoisture, precipitation, approximate anmual rainfall and precipitation during the growing period.)

Species sown singly.

Species sown to a mixture

Source of seed

(Cood, average, poor, germination test.)

Quantity of each species of seed per acre.

Preparation of the soil.

(Plowed, harrowed, brushed, tramped in, ete.)

Method of sowing. (Broadeasted or drilled in.)

Was seed well covered?

Cost of Ranger labor.

Cost of outside labor.

Total cost of sowing per acre, including seed

(Signature.)

Date of report.

(Title.) 
Progress Report on

Grass Seeding Station

National Forest.

(To be submitted July 1 and October 1.)

$191 .$.

Area.

Sirip No

Established $191 \ldots$

Location

(Time since seeding.)

(Time of germination.)

(Are any dormant seed found?)

Density of stand.

(Approximate number of seedings per square yard.)

(Is stand uniform?)

Species predominating

(If seed was of but one soturee, this need not be fillecl in.)

Soil moisture at this time.

Light conditions and competition

(State if weeds and native species arc overshadowing and crowding out seerlings.)

Root development

(Note depth and spread.)

Would seedlings be pulled out of ground if grazed?

Approximate precipitation since seeding.

(Climatology, considered farorable or unfarorable.)

Height growih

(Average length of blades and entire plant.)

Protection 
Loss of seedlings due to grazing

Remarks

(If experiment is failure, show cause; if it has any noticeable drawbacks, note them.)

(Suggestions for improvement in continuing the experiment.)

(Reference to special letters written concerning improving the experiment.)

(Signature.)

(Title.)

Date of report....................., $191 \ldots$

The time of sowing and the subsequent treatment is quite as important as the selection of the species. In nearly all localities (notable exceptions being marshy meadows and swales,

Spring versus fall where the seed is liable to decay) fall seeding is
seeding. seeding. usually much more successful than sowing clone in the spring. In all seeding the ground can be worked more satisfactorily, which materially increases the per cent of germination and the seed coat, being thoronghly soaked and softened by the soil moisture, germinates as soon as the temperature becomes favorable. This results in the formation of a deep root system and better chances of survival through a later drought period, since seed sown in the spring germinates later, the resulting stand being relatively low, and a high per cent of loss follows when the surface layer of soil dries out. 


\section{REPORTS.}

Forest rangers will make quarterly reports on the condition of Rangers to super- the stock and the range minler their cliarge in accordvisors.

ance with the outline on Form 658 , when 50 per cent or more of the permits on the grazing district are year long. If less, these reports will be made on June 30 and September 30.

In the report for the quarter ending September 30 rangers will include the approximate number of stock grazed free uncler the tenhead exemption. (See "Stock exempt from permit," p. 22.)

The Supervisor may require from each ranger with the quarterly

Mortality reports. leport, or oftener if necessary, a report on stock mortality covering the number of animals of each class discovered on the district during the period covered by the report dead of discase, accident, wild animals, poisonous plants, and starvation. 'The disposition of the careass should be noted in earh case.

Rangers or guards counting stock entering the Forest will report counting report. to the Supervisol on Folm 874-18 as soon as possible alter each count.

Permits issued under Regulation G-19 should be based upon a Grazing capacity fieli estimate of the grazing capacity of the lands of private lands. involved. Plivate lands withim a langer's district may be examined when the application is made, or in advance of application at any time an opportunity oceurs. Reports will be made on Form 251.

When required by the Supervisor, officers employed as hunters will submit a report (Form 34.3) showing the work accomplished since the last report.

\section{Grazing Chapter, Supervisor's Annual Forest Plan.}

Is a matter of convenience to the stockmen it is desirable to make public as soon as possible the number of stock that will be allowed to graze on the Forest the following season, the periods and the fees. 'Therefore, immediately after the close of the grazing season and not later than December 1, Supervisol's will submit the "Glazing" "hapter of the ammual forest plan in duplicate, forwarding it to the District Forestel without waiting for the completion of the rest of the plan. The following points will be covered:

A statement of amount of rainfall and forage as compared with General rangecon- other years. The conditions of the range at the elose ditions.

of the season, and whether or not any portion of it is being injured by overgrazing. The condition of the stock at the time of entering and leaving the Forest. Market conditions and sales of stock during the season. Matters of general interest concerning the welfare of stock grazing upon the Forest. 
Proposed changes in the grazing distriets. The division of the Range dirisions. districts between different kinds of stock. Closing areas against sheep, goats, cattle, horses, or hogs, for the protection of watersheds or of the Forest. The distribution of the stock upon the range changes in the number allowed upon districts or dirisions. The establishment of driveways and restrictions in their use.

General plan adopted in the approval of applications. Special Permit allotments. rules for allotments. The establishment of protective or maximum limits.

Losses of stock from poisonous plants and the need for investigaProtection. tions. Prevalence of predatory animals and the need for the appointment of hunters. Prairie dogs and need for their extermination. Need for scientific inrestigation to determine a practical means of reseeding the range.

The approximate number of owners and of each kind of stock stock grazlng grazed free under regulation. without permit.

Degree of cooperation received from stock associations. Methods Live stock associa- used in settling controversies and adjusting range tlons. disputes.

An estimate of the grazing capacity of National Forest lands only,

Estimating grazing counting stock 6 months old, but figuring on the capacity. natural increase.

Increase or decrease in the total number of each class of stock to Recommendations. be grazed on the Forest during the coming season, the distribution of the stock between districts. Grazing periods in different portions of the Forest and for different classes of stock. The fees to be charged for each class of stock. Special rules to meet local conditions. The issuance of five-year permits. (See Reg. (r-1.)

The Supervisor will prepare a map of the Forest in duplicate, suitGrazing map. able for insertion in the Forest Atlas, to accompany the grazing chapter. It will show grazing district, areas open to each class of stock, lambing grounds, driveways, overgrazed areas, areas closed to any kind of stock, and areas which can not be utilized for grazing.

The Supervisor of a National Forest having a National game preGame preserves. $\quad$ serve within its limits will include in his annual plan full information on the condition of the forage within the preserve, the estimated number of game animals occupying the range, their condition and the permanent improvements necessary. Recommendations will be made regarding all matters which demand action.

\section{Grazing Section-Supervisor's Annual Statistical Report.}

A report on the printed form in aceordance with the instructions thereon, giving the required data and information on the following subjects: Grazing permit; Classification of permits; Crossing permits and permits on account of private land; Predatory animals killed.

This report is due with the District Forester on July 15, and will cover the preceding fiseal year. 
When this report is compiled, the record cards (Forms 621 and 256) for permits issued since July 1 of the preceding year and for the current grazing year may be checked with a blue pencil in the "Number applied for" column.

When the data is prepared for the classification of permits by grades, the record cards may be checked as above with a red poncil.

After the annual statistical report has been prepared, the record cards for the previous grazing year will be transferred to the closed files.

\section{District Forester's Report.}

Upon receipt of the Supervisor's grazing chapter the District Annual District oflice of Grazing will take the action outlined under plan. "Allotments," p. 20.

On receipt of all the Forest Statistical reports the District Forester

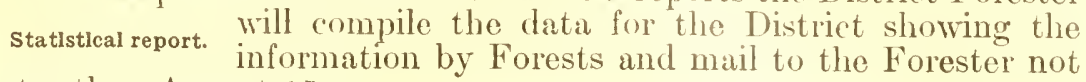
later than August 15.

$86104^{\circ}-11-6$ 


\section{GRAZING FORMS.}

Form 879

(Revised March 18, 1911.)

\section{UNITED STATES DEPARTMENT OF AGRICULTURE FOREST SERVICE}

\section{APPLICATION FOR GRAZING PERMIT}

No.

(Date.)

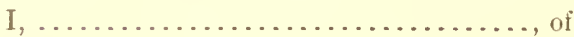

of

(Place of residence.)

do hereby make application for permit to graze

head of horses, .......... head of sheep, and

(Number.)

(Number.)

(Kind of stock.)

upon lands of the United States within the National Forest, from 191 191 , and also.

(Lambing specified number of ewes included in aforesaid sheep, or other additional use.)

My marks and brands are as followy: BrandsEarmark-

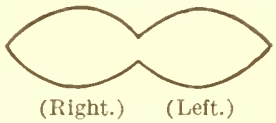

It is my desire to graze the said animals upon that part of the Forest described as follows:

Provided, That they shall not intrude upon any areas upon which grazing is prohibited.

I do hereby certify that -

1. This application is made for my own exclusive use and benefit, and not directly or indirectly for the use of any other person.

2. My home ranch is located in...

(Give location by township, range, or section, if surveyed.)

3. I own...........acres of improved farming land upon which hay or grain is (Number.)

Note.-Animals under 6 months old at the time of entry whlch are the natural increase of stock grazed under permit will not be counted. 
raised, and also. acres of summer grazing land, and...............eres of (Number.)

winter grazing land, located in the counties of . .

4. I now actually own...........head of. (Number.) ancl.

(Kind of stock.)
(Number.)

head of ..................

(kind of stock.)

$5 . M y \ldots \ldots \ldots \ldots \ldots \ldots \ldots \ldots \ldots \ldots$ are ranged, during the winter season, on (kind or kinds of stock.)

(Give township, range, and section, if range is owned or leased by applicant. If on pubile range, so state.)

(If stock is fed, give location of ranch and amount of hay used.)

6. I have regularly used range now in the.................... Fational Forest

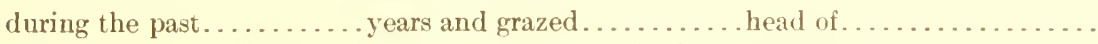
(Number.)

(Number.)

(Kind of stock.)

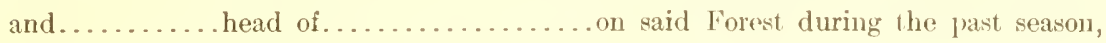
(Number.)

( ind of stock.)

from............ to ..........

(Date) (Date)

7. I have not made application for a grazing permit in any other National Forest, except as follows:

If this application is granted, in whole or in part, I do hereby agree to deposit the amount due for grazing fees to the credit of the Treasurer of the United States in the U. S. Depository designated by the letter of transmittal.

I also hereby bind myself and my employees engaged in caring for the animals while on the Forest to extinguish all camp fires started by myself or any of my employees before leaving the vicinity thereof, and to render all reasonable aid in extinguishing forest fires within the distriet in which the stock is grazed, such service to be without eompensation if required to protect the grazing area allotted to me and described in my grazing permit, but at the prevailing rate of compensation if otherwise.

I also hereby agree that I will allow my stock to graze only upon lands of the United States within the areas specified in the permit, that I will obey and support all the laws and regulations governing National Forests, and that I will pay for all damage sustained by the United States through any violation, by myself or my employees, of such laws or regulations, or of the terms hereof or of the permit issued upon this application.

I also agree to forfeit the permit whenever the National Forest for any reason ceases to exist, or for a violation of the National Forest regulations now or hereafter adopted or of any of the terms hereof, or of the terms of the permit issued hereupon, or whenever any injury is being done to the Forest by reason of the presence of the animals therein.

Approved............., 191 ,

(Date of approval.)

(Signature of applicant.)

for . . . . . . cattle, ......... horses,

(Number.) (Number.)

sheep.

(Number.)

(Post-office address.)

(Signature of Forest officer.)

(Title.) 
Form 298

(Revised March 18, 1911)

\section{UNITED STATES DEPARTMENT OF AGRICULTURE FOREST SERVICE \\ APPLICATION FOR GRAZING PERMIT, FIVE=YEAR PERIOD}

No.

(Date.)

$\mathrm{I}$,

(Place of residence.)

do hereby make application for permit to graze $\ldots \ldots \ldots .$. head of cattle, ........ (Number.)

(Number.)

hear of horses, .......... head of sheep, and . .

(Number.)

(Number.)

(Kind of stock.)

upon lands of the United States within the

National Forest, from for a period of five years, beginning to lege of .

(Lambing specified number of ewes included in aforesaid sheep, or other additional privilege.)

My marks and brands are as follows:

Brands-

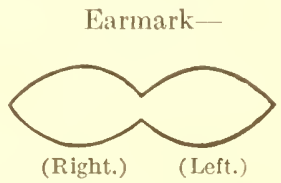

It is my desire to graze the faid animals upon that part of the Forest described as follows:

Provided, That they shall not intrude upon any areas upon which grazing is prohibited.

I do hereby certify that-

1. This application is made for my own exclusive use and benefit, and not directly or indirectly for the use of any other person.

2. My home ranch is located in

(Give location by township, range, or section, if surveyed.)

3. I own ........... acres of improved farming land upon which hay or grain is (Number.)

Note.-Animals under six months old at the time of entry which are the natural increase of stock grazed under permit will not be counted.

(OVE1.) 
raised, and also acres of summer grazing land, and acres of

winter grazing land, located in the counties of ...

4. I now aetually own $\ldots . . . .$. . head of (Number.)
(Kind of stock.) and

(Number.)

head of.............

(Kind of stock.)

5. My are ranged, during the winter season, on (Kind or kinds of stock.)

(Give township, range, and section, if range is owned or leased by applicant. If on public range, so state.)

(If stock is fed, give location of ranch and amount of hay used.)

I have not made applieation for a grazing permit in any other National Forest, except as follows:

If this application is granted, in whole or in part, I do hereby agree to pay to the National Bank of (U. S. Deposi-

tory), or such other depository or officers as shall hereafter be duly designated by the United States, to be placed to the eredit of the Treasurer of the United States, the amount due for grazing fees for a period of five years annually in advance at the regular rate fixed each year for the said National Forest on the full number of animals for which my application is approved, and to use the range each year unless the Forest Supervisor agrees that it should be given a rest.

I also agree that the annual permits issued to me shall not be transferable, but it is agreed that if the stock is sold a pernit may be issued to the purchaser allowing him to continue grazing it on the National Forest range until the expiration of the annual period for which the fees have been paid.

I also hereby bind myself and my employees engaged in caring for the animals while on the Forest to extinguish all eamp fires started by myself or any of my employees before leaving the vicinity thereof, and to render all reasonable aid in extinguishing forest fires within the district in which the stock is grazed.

I also hereby agree that I will allow my stock to graze only upon lands of the United States within the areas specified in the permit; that I will obey and support all the laws and regulations governing National Forests; and that I will pay for all damage sustained by the United States, through any violation, by myself or my employees, of such laws or regulations, or of the terms hereof, or of the permit issued upon this application.

I also agree to forfeit the permit whenever the National Forest for any reason ceases to exist, or for a violation of the National Forest regulations now or hereafter arlopted, or of any of the terms hereof, or of the terms of the permit issued hereupon, or whenever any injury is being done to the Forest by reason of the presence of the animals therein.

Approved............., 191 ,

(Date of approval.)

for...........cattle.

(Signature of applicant.)

(Number.)

(Number.)

sheep.

(Post-office address.)

(Number.)

(Signature of Forest officer.)

(Title.) 
POSTAL CARD NOTICES

Form 153

UNITED STATES DEPARTMENT OF AGRICULTURE

FOREST SERVICE

M.

DEAR SIR:

Applications for permits to graze.

on the.................... National Forest during the season of 191 must be filed in my office on or before. 191

Application blanks and full information in regard to grazing periods and fees to be charged may be had upon request.

Supervisor.

Form 303

UNITED STATES DEPARTMENT OF AGRICULTURE

FOREST SERVICE

DeAr Sir:

Your application for a grazing permit on the................

National Forest is received, and you will be notified of the action taken in due time.

Very truly, yours,

Supervisor.

86 
SEE OTHER SIDE FOR INSTRUCTIONS-READ CAREFULLY

Payment must be made before beginning of the grazing period. 191.

The National Bank, United States Depository,

There is inclosed herewith a (1) $\left\{\begin{array}{l}\text { Money order } \\ \text { Draft }\end{array}\right\}$ for dollars, draun payable to your order, to be placed to the credit of the Treasurer of THE UNITED STATES. This deposit is on acrount of an application dated .......... 191... for a permit to graze ..... head of .............. head of head of ..........., upon lands of the United States within the National Forest, which has been approved for ...... head of head of hearl of $\ldots . . . \ldots$.

the stock to be allowed in District No.

from $191 \ldots, t 0$ 191 (2) (Signature of payer)

(3)

(Post office)

(Permit No.) (Supervisor)

(Name)

Deposit on account of grazing permit,

National Forest.

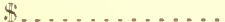

[Reverse side-Form 86 G] INFORMATION FOR PERSONA MAKING PAYMFNTS

Indicate in the space marked (1) the character of your remittance, in (2) your name, and in (3) the address to which you wish the receipt sent. Failure on your part to make payments in the following nanner will delay business: Make payments by postal or express money orders or by National Bank drafts, DRAWN PAYABle To The

National Bank. Do not send personal local checks. Send paynent with the copy of this form furnished you by the Forest officer to The ..... National Bank,

\section{INSTRUCTIONS TO FOREST OFFICERS}

Furnish this form to persons making payments for grazing permits. Enter in the spaces provided the amount of the remittance, date of application, number and kind of stock permit is applied for, number application is approved for, district stock will be grazed upon, and period during which grazing will be allowed. Send a duplicate copy to the District Forester and file a triplicate copy with the other papers in the case. Do not use this form for any payments except those on account of grazing permits. 


\section{UNITED STATES DEPARTMENT OF AGRICULTURE} FOREST SERVICE

\section{GRAZING PERMIT}

(This permit is not transferable.)

No.

(Date.)

M. . . of (Place of residence.)

(Name)

to the

National Bank of

(U.S. Depository)

the grazing fee amounting to the sum of dollars $(\$ \ldots .$.$) , is$ hereby authorized to pasture the following number and rlass of live stock:

and head of

branded or earmarked as follows:

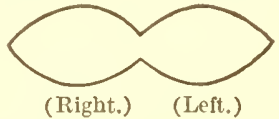

upon lands of the United States within the National Forest from $191 \ldots$, to $191 \ldots$

Provided, That the animals shall not intrude upon any area upon which grazing is prohibited, nor upon any portion of the Natiomal Forest except the following-described area:

This pernit is issued in consideration of the promises and agreements made by said in his application No. dated $191 \ldots$

This permit is issued with no obligation or agreement on the part of the Government to maintain an exclusive possession upon any part of said Forest to any one person or firm, nor as to adjustment of any conflict as to possession.

For a violation of any of the terms of the application on which it is based, or whenever any injury is being done the Forest by reason of the presence of the animals therein, this permit will be canceled and the animals will be removed from the Forest.

Supervisor.

NorE.-Animals under six months old at the time of entry, whlch are the natural increase of stock grazed under permit, will not be counted. 
Form 925

(Revised March 15, 1911)

\title{
UNITED STATES DEPARTMENT OF AGRICULTURE
} FOREST SERVICE

\author{
APPLICATION FOR PERMIT ON ACCOUNT OF PRIVATE LAND
}

$191 \ldots$

$\mathrm{I}$,

being the owner, or lessee, of lands described as follows:

and located within the.

National Forest, do hereby agree to allow the free and unrestricted use of the saicl private lands by all stock permitted to graze on the adjoining National Forest lands, provided that in exchange for such use of the said private lands, I an permitted to graze...........

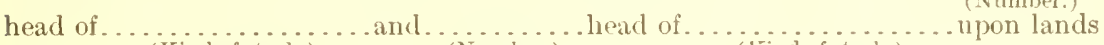
(Kind of stock.) (Number.) (Kind of stock.)

of the United States described as follows:

within the said Forest, from.

(Dite.)

(Date.)

during which period the said private land will adequately support the number of stock above mentioned.

I hereby bind myself and my employees engaged in caring for the animals while on the Forest to extinguish all camp fires started by myself or any of my employees before leaving the vicinity thereof, and to render all reasonable aid in extinguishing forest fires, such service to be without compensation if required to protect the area embraced in the permit, but at the prevailing rate of compensation if otherwise.

I also hereby agree that I will allow my stock to graze ouly upon the areas specified in the permit, and that I will obey and support all the laws and regulations governing National Forests.

I also agree that the permit shall become null and void whenever the National Forest for any reason ceases to exist, or for a violation of the National Forest regulations now or hereafter adopted or of any of the terms hereof, or whenever an injury is being done to the Forest by reason of the presence of the animals therein. I also agree that during the period the permit is effective I will not allow the use of the above described private lands by any stock other than those permitted to graze upon the adjoining National Forest lands.

Approved..................., 191...

(Signature of applicant.)

(Signature of approving officer.)

(Post-office address.)

(Title.) 


\section{CROSSING PERMIT}

191.

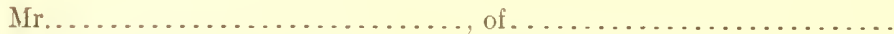

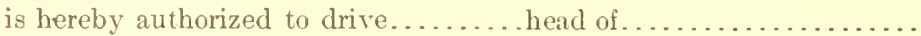

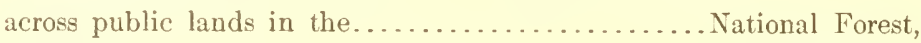
between ..............., 191 .., and .............., 191..,

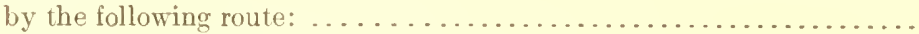

This permit is issued subject to all rules and regulations governing National Forests.

(Title of Forest officer.)

\section{Form 976}

U. S. DEPARTMENT OF AGRICULTURE FOREST SERVICE

\section{HERDER'S IDENTIFICATION CARD}

$\mathrm{Mr}$.

having been granted Permit No.... to graze.....head of..... within the.............. Tational Forest during the season of $191 \ldots$, is a uthorized to divide the animals into.... herds, one of which, designated as Herd No. ....., shall not contain more than.......head, and be in charge of

$\mathrm{Mr}$.

(If herder be changed, draw a line through name and enter new name on next line.)

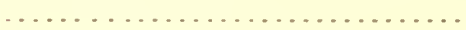

\section{Forest Supervisor.}

This card must be presented upon demand of any Forest officer.

(OVER)
(Reverse side, Herder's Identification card.)

\section{NOTICE}

The holder of Grazing Permit No. ..... has agreed for himself and his employees to comply fully with all rules and regulations governing National Forests, to extinguish all camp fires before leaving the vicinity thereof, and to aid in extinguishing all forest fires in the territory occupied by him or them. It has also been agreed that when injury is being done the Forest by reason of the presence of stock grazed under pernit, the animals will be removed.

These stipulations will be rigidly enforcel.

The herder whose name appears on this card is particularly warned that building a fire upon the public domain, in or near a National Forest, and leaving said fire without totally extinguishing same is a crime, and any herder who commits such an offense will be prosecuted criminally to the full extent of the law. Forest officers have the right to arrest without a warrant any person caught violating the regulations governing $\mathrm{Na}$ tional Forests. A herder who knowingly suffers or permits cattle, sheep, or other live stock under his care or contract to go upon lands in a $\mathrm{Na}$ tional Forest not embraced in a permit duly issued by an authorized officer of the Forest Service, is subject to prosecution therefor. 
Form 763

(Revised March 18, 1911)

\section{UNITED STATES DEPARTMENT OF AGRICULTURE FOREST SERVICE WAIVER OF GRAZING PRIVILEGE}

This Memorandum witnesseth that:

WhEREAs the undersigned, under date of. , received from the United States Department of Agriculture, Forest Service, a permit to graze......................... of.

National Forest; and WHEREAs such permit is understood to carry with it, in the discretion of the Forester, subject to necessary reduction, and upon the request of the permittee, a continuation of such privilege from year to year; and

Whereas the said undersigned, has sold to of head of . ; and

Now, THEREFORE, the unclersigned,

does hereby surrender unto the United States all privileges whatsoever allowed under the aforesaid permit and any such further continuance of the privileges thereunder as may be carried by the issuance of the said permit; and further, the said undersigned, does stipulate that........ will not at any future time apply for a renewal of the said permit as to the............ head of................. sold as aforesaid.

Executed this. day of. . . 191.

\section{Witness:}




\section{Form 377}

\section{UNITED STATES DEPARTMENT OF AGRICULTURE}

\section{FOREST SERVICE}

\section{BOND}

Know All Men by these Presents: 'That we.

(Names of principals.)

as principal , and

(Names of sureties.)

unto the United States of America in the sum of.

, are bound $(\$$. ), for the payment of which sum well and truly to be made to the National Bank of. (U. S. depository) or such other depository or officers as shall hereafter be duly designated by the United States, to be placed to the credit of the United States, we bind ourselves and each of $\mathrm{ns}$, our and each of our heirs, executors, administrators, successors, and assigns, jointly and severally, firmly by these presents.

The condition of this obligation is such that whereas the above-bounden.

(Names of principals.)

ha by a certain.

(Application or agreement.) (Signed or executed.)

day of................., 191, made application for the privilege of grazing .........head of .................. upon lands of the United States in that part of the................. National Forest, described in said application as follows:

and has agreed, if said application should be granted in whole or in part, to pay as therein provided the amount due for grazing fees, to obey and support all the laws and regulations governing the National Forests, to allow his stock to enter or graze only upon lands of the United States within the area specified in the permit issued upon such application, and to pay for all damage sustained by the United States through any violation, by him or his employees, of the aforesaid laws or regulations or of the terms of such application or of the permit issued thereupon. 
shall well and truly perform all and singular the promises in said...

(Application or agreement) then this obligation shall be void, otherwise to remain in full force and effect.

In Witness Wheneof, The parties hereto have executed this instrument this ..... day of , 191 , at

(Corporate seal, if corporation)

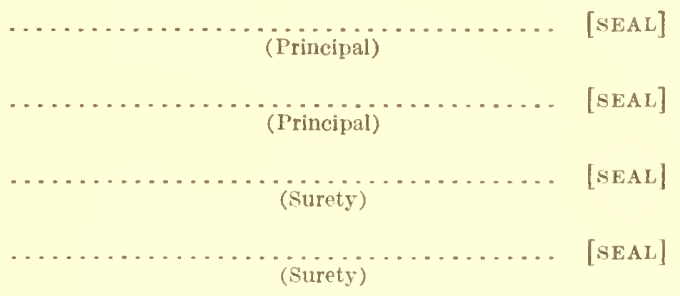

\section{ACKNOWLEDGMENT OF PRINCIPAL.}

State of ....., County of ...., ss:

On this day of 191 , before me a (Name of notary)

notary public, in and for ...................... residing therein, duly sworn and acting under a commission expiring ............., 19 , personally appeared

known to we to be the ......... of the (Title.)

\section{(Name of purchasing company)}

the corporation that executed the above instrument, and known to me to be the person who executed the above instrument in bchalf of the said corporation, and ...... acknowledged to me that he said corporation executed the above instrument, as principal, voluntarily for the uses therein specified.

WrTness my hand and official seal the date first in this certificate above written. [SEAL]

$$
\text { Notary P̈ublic. }
$$

N. B.-Italics are to be stricken out when bond is executed by individuals and not by corporations. 
State of ...., County of ...., ss:

On this day of

191 , before me.

(Name of notary)

a notary public, in and for residing therein, duly sworn and acting under a commission expiring. 191 personally appeared

\section{(Names of sureties)}

known to me to be the ......... of the

(Title)

(Name of surety company)

the corporation that executed the above instrument, and known to me to be the person who executed the above instrument in behal fof the said corporation, and each acknowledged to me that he said corporation executed the same as surety, voluntarily for the uses therein specified.

Witness my hand and official seal the date first in this certificate above written.

[SEAL]

Notary Public.

N. B.-Italics are to be stricken out when bond is executed by individuals and not hy corporations.

\section{OATH OF SURETIES.}

\section{(Must be used when individuals are sureties.)}

State of ...., County of ...., ss:

(Name of surety) $\ldots \ldots \ldots \ldots \ldots \ldots \ldots \ldots \ldots \ldots \ldots$ and $\ldots \ldots \ldots$ (Name of surety)

being duly sworn, each for himself says that he is a ritizen of the United States and a resident of ................... that he signed the above bond as one of the sureties thereon; that he is worth the sum of in property in the .............. of his residence over and above all legal liabilities and exemptions, and that he has property therein subject to sale on execution worth the sum of

(Surety)

(Surety)

Subscribed in my presence by

(Name of surety

and Name of surety)

and by each of them sworn to before me this day of 191

Wrtenss my hand and official seal the date last above written. [SEAL]

Notary Public in and for the County of

State of

My commission expires

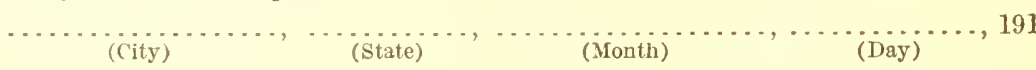

Approved:

(Signature of approving officer) 
Page.

Act of June 4, 1897

Advisory looards:

Action on recommendations.............. Application for recognition

Card record................

Disapproval of recommendations..........

Disapproved applications of ..............

District forester informed of .................

Duties of . .

Duty in appeals ........................

Forester to be informed of .................

For national association................ 15, (i)

For State................................ 15,61

How formed....................................

How recognized...................... 14

Matters submitted to be general.......... fil

May appeal.......................... 61

Meetings of ................................

More than one on a forest...............

llienated lands, not to be considered......... 18

Aliens, permits to . .........................

Allotments.

Boundaries of, to be markeri..................

Individual, allowance for strays..........

Individual, map of . ....................

Individual range.

For game animals . . . . . . . . . . . . . . . .

Permit, report of

Regulation concerning

To be entered on back of permit...............

Allowance:

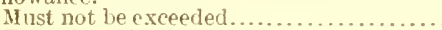

For private lands............................

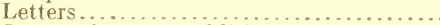

On new forests or additions.....................

Stock not chargeable against ..................

Amended, form to be markerl..................

Immunition, will be furnislzed.............

Animals:

Exempt from permit...................

Predatory

Under 6 months of age..................

Annual forest plan, grazing chapter of......

Annual reductions ........................

Anthrax, aninials dying from...................

Appeals

Duty of district forester...................

Field investigation of ....................

instructions concerning........................

Method of making.......................

Must be in writing........................ 13

Must file within 10 days............... 51

Of advisory boards ...................... til

Persons making may inspect records.........

Reconsideration of........................

Supervisor's decision.

Supervisor to forward record..............

To Forester, additional statement may be filed

To Secretary of Agriculture

To Secretary, Forester to submit all paners.

Use of range during consideration....

Applicants:

Classes $\mathrm{A}, \mathrm{B}$, and $\mathrm{C}$

May be both $B$ and $C$ class.............. 10,3.

New, oll fully stocked forests..............

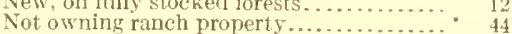

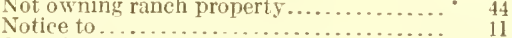

Qualifications of..

Status, how determiner

Who own two classes of stock...............

ipplications:

Action unou

Amended, how numbered

Amended or corrected, should be marked.

Amendment of

Canceled, number not used again............ Cancellation of ............................

Card record of

Classification of new .

168

61

(i)

bil

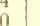

(il

2

A pplications-Continued.

Disapproved, applicant furnished reasons.. .

Failure to file in time..................

For crossing permits ..................... 54

For five-rear period................... 19

For five-year period, annual reduction..... 20

For more than one period................. 41

For permits, form of ................... 89

For permits, use of private land............ 57

For permits, general procedure........... 41

For permits, liow sulmitted..............
For permits, in two forests...............

For stock not authorized.................. 17

For term permits.................... 41,44

From cooperative associations........... 3t

From indicted person.....................

From married women .....................

From minors ......................... $\quad 37$

From new owmers...................... 11

From new settlers filed six months in ad-

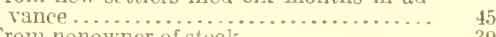

From nonowner of stuck.................. 39

From nonresidents...................... 38,44

From unmarrjed women.................. 37

May lie approved subsequently........... 40

Mav be rejected ....................... 29

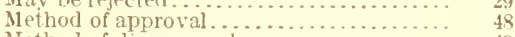

Method of disapproval..................... 49

Must be received before................. 40

Not filed within......................... 11

Not to be approved before date............. 40

Notification of ........................... 40

Of advisory boards, disapproved......... 61

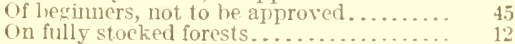

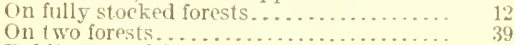

Prullication of date for.................... 49

Receipt of acknow]etged................ 40

supervisor may require statement...........

supplemental........................ 41

To lie filed six months hefore.............. 12

To be num bered................... 4s

Inusual conditions to lie noted........... 4 .

When disapproved applicant notified..... 49

When stock is sold after approval......... 47

IV ithout intention to use................... 29

Approval, duplicate notices of ........... 49

reas:

Poisonous plant ..................... 23

Protected, houndaries of.....................

Supervisor may close.......................

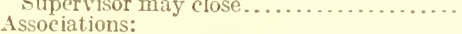

Advisory hoards of State...............

Attendance at meetings .................. 62

Complaints by members.................. 61

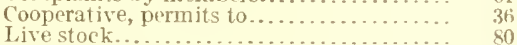

National live stock.........................

Privileges allowed...................... 36

When dishanded .........................

Attendance at meetings......................

Bedding shecp and goats:

During lambing season................ 15

General instructions................. tiō

More than six nights in one place........... 15

Near stream or spring.................. 65

Beginners:

General instructions regarding. ..

Total number allowed must not exceed..... 4.5

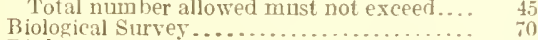

Bird ref11ges......................... 71

Birds, protection of ...................... 69

$\begin{array}{ll}\text { Blackleg, animals dying from................ } & 65 \\ \text { Boards, advisory, regulation concerning.... } & 14\end{array}$

Bonds:

Basis for amount.................... 54

From trespasser.................... 54 
Page.

Bonds-Continued.

Reasons for requiring.

Supervisor may require.

Supervisor will prepare.

Where filed

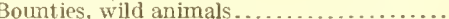

Brome grass, sowing of...

Bureau of Animal Indnstry...............

Bureau of Fisheries, United States...........

Calf tally, count based upon.................

Camping places, protection of..............

Capacity:

Determination of range capacity..........

Estimating grazing capacity.

Carcasses:

Disposition of ...

To be burned or buried. Card:

Herder's identification

Identification, form of . . .

Identification.

Card record:

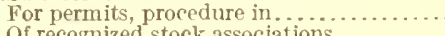

of recognized stock associations.

Cards:

Postal notices.

Record, cross references to he made..........

Record, may be checked

To be filed alphabetieally

Carrying capacity, of certain classes of land. .

Cattle:

Counting of.

Improved methods of handing.

Census, of stock. .

Change of residence, does not disqualify....

Class A.

Applicants...

Owners.

Owners, protective limits for

Class B, applicants.

Class C.

Classification:

Of applicants.

Of owners.

Complaints:

Action will not he reverser when ...

Method of handling...

Controversies:

Settlement of.

Settlement of, procedure governing.

Supervisor will decide.

Contents, tahle of.

Cooperative associations . .

Copartnerships and corporations................

Copartnerships and incorporated companies, permits to

Corporations (see Copartnerships)

Loeal or foreign.

Corrals, for capturing wild horses.

Correeted, form to lic marked.

Counting corrals.

Counting stock

At round ups.

By calf tally.

By sales records.

Instruetions regardin

Range estimates.

When an exact count impossible.

Crossing pernits (sce Private lands).

Form of.

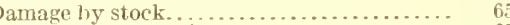

Stockmen to repair......................

Damage to roads........................ 15

Dead animals, disposition of.............. 6.

Decision of court, not anticipate.............

Delinquent, supervisor will notify............. 49

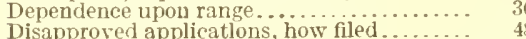

Diseases, infectious or contagious........ 15, 65,67

Disposition of carcasses................ 65,79

Districts and divisions .................... 23

Supervisors to make....................

Districts:

Forest to be divided into

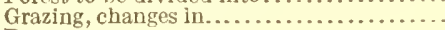

Ranger.
Page.

Division, grazing.................... 23, 24

Divisions:

Designation of ....................... 24

Smaller than district................. 24

Drivewars:

Duty of rangers ...................... 25

Estal.lished by district forester...............

Grazing of stock en route................... 25

Permits required for.................. 25

To be marked............................ ${ }_{25}$

When necessary ....................... 25

Emergency concessions.................. 29

Estates, permits to ....................... 37

Examination of records, conditions of ....... 52

Exclusion of stock..................... 23

Exemptions from permit . ................ 22

To Indians ......................... $\quad 22$

Federal emplorces, permits to .............. 38

Fees (sce also Rates):

Based upon yearlong rate .............. 9

Determined by district forester.......... 17

Determined by Forester................. 17

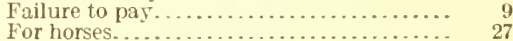

For lambing............................ 28

For periods shorter than yearlong........ 9,26

For swine.......................... 27

Fractions of cent ...................... 26

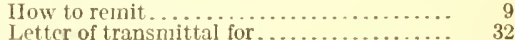

Method of estallishing................. 9

Nompayment of.......................... 29

Not pairl, supervisor will notify..........

On all animals except.................... $\quad 26$

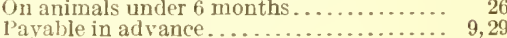

l'rocedure in payments....................

Proportion of sheep to cattle............... 27

Reduction in ....................... 19

Refund of .......................... 10,29

Refund, approved by district forester..... 29

To be charged.........................

Transfer of .................................. 54

Fees and bounties, for killing predatory ani-

mals............................ 69

Fifteen days, before or after permit ........... 19

Files, closed ......................... $\quad 81$

Fines:

Forest officers not to receive $\ldots \ldots \ldots \ldots \ldots \ldots$.
Mfay not accept.............................

Firms (sce Copartnerships)................... 11

Use of range by..................... 37

Or corporations, may be required to furnish 41

Fish:

For stocking streams.................. 70

Protection of ......................... 69

Five-year periods (see Term permits) .......... 20

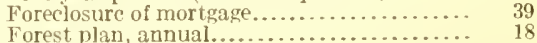

Forests:

Idditions to ......................... 10

Fully stocked.............................. 12

Form $153 \ldots \ldots \ldots \ldots \ldots \ldots \ldots \ldots \ldots \ldots \ldots \ldots \ldots, 40,86$

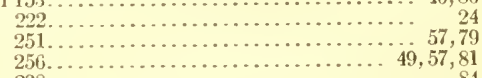

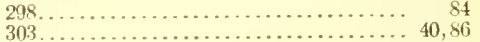

$343 \ldots \ldots \ldots \ldots \ldots \ldots \ldots \ldots \ldots \ldots \ldots \ldots \ldots \ldots \ldots \ldots \ldots, 68,79$

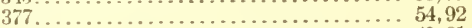

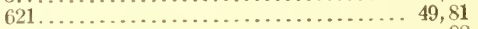

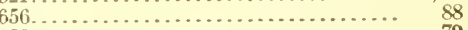

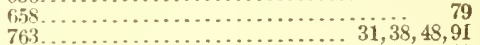

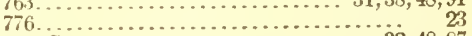

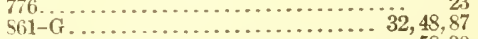

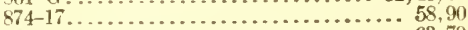

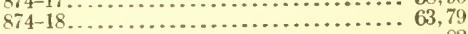

879.

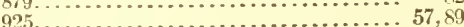

$976 \ldots \ldots \ldots \ldots \ldots \ldots \ldots \ldots \ldots \ldots \ldots \ldots \ldots \ldots \ldots \ldots \ldots \ldots \ldots \ldots, 64,90$

Free grazing, for Indians.................... ${ }_{22}$

Game:

Fish, stocking of streams.................

70 
I'axe.

Game-Continued

Protected areis for...

Protection of

Protection of, district officers to enforce.

Range allotments for

Game laws....

Distriet forester will cooperate.

Dutius of forest offieers...

rines for enforcement of ..............

printed copies of...................

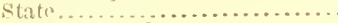

To be enforeed

Game preserves.

state.

Game preservation, cooperation with state.

Game wardens...

ipjointment as

dianders, animals dying from

Goats:

Improted methods of handling...

Not allowed luntil.

Grazing:

A nnial grazing, instructions for

Authority of Secretary to permit...

Capacity of tands.

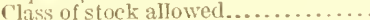

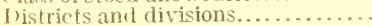

ofject of regulations..

On driveways.

On private lands.....

Period, 15 days added.

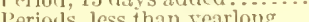

Regulations, are supreme...........

Yearlong fees.

Chapter, annual forest plin. ...

Chapter, aunual district plan

Districts...

Estimate, lands includer in...

Fees.

Irap, must show areas, etc., with annual plan.

Periods...

Preferences-

Conditions of ...

llow acquired.

Ilow gained

Value of.

Privilege-

A personal one

No law giving right to

Not transferalsle.

Prior occupancy...

Temporary one.

Waiver of

Wraiver of form of .................. 38.39

Heirs, minor...........

Horses:

Counting....

Yearlong rates

Hunters:

Appointment approved, hy grazing ... . .

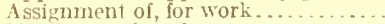

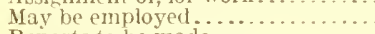

Reports to be made..

Reportis to supervisors...

Identifieation cards.

Form of .

Improvement, methods of range.

Indians, free grazing for .

Indictment, not justified, disapproval....

Indiviclual ranges.

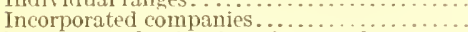

Increases and reductions, how made.

Instructions:

To forest officers.

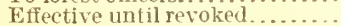

Kidding (sce Lambing). .

Lakes and streams, protection of.

Lambing:

On and off....

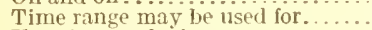

Use of range during.

Charges, reasons for.

Groumds, eontrol of ....

Or kidding, use of phrase.
Lands (sec Private lands):

Can not be leased.

Page.

Covered by stiate selection: ....

Private, exchange of proceclume.......... 57

Private, statement of ownership..........

Railroad.......................... 57

Squatters upon, lunsirveyed............. 57

Ensurveyed within indemnity limis.....

Laws:

Game, if inadequate................... 76

State or Federal, violation of ............

Stale, when effective................... 23

Stock, duty of rangers rexarding.......... 67

Leases, no authority for . ................ $2_{2}$

Leasing stork........................

leasing system, not practical............ $26 i$

Limit:

Higher on sheep tluan eattle. . . . ........ 4 .

Maximum.............................. 11,

District forester miny susperid . ........ 11

Does not apply to certain jermits...... 43

Exception to rule................... 43

How established. . .......................

Permit in excess of ...................

Relluetions in ........................ 42

of livisions, stock to be kept within. ..... 21

Protective and maximum.............. 49

Protective, district forester will establish... 1I, 4 .
Protective, when stock is less...........

Live stock. (Scc stock.)

Map, to aceompany annual plan............ so

Marrief women, applications and permits... 37

Maxinum limits, how estiblished ..........

Meetings, attendanee at. ................ 62

Mileh or work animals.............. $s, 22$

Mining claims:

Grazing on unpatented ................. 56

Right of owners to dispose of grazing

Unperfected, can not be accepted.......... 54

Minors, instructions concerning............

Mortality reports.............. 79

National live-stork associations............. bi

Newly created forests, grazing use of ....... 10

New settiers:

Must file applieations in advance........ 45

Policy of recognizing ................. 34

Nonresidents, owners of stock............. 38

Notification of applicants, procedure........ 49

Numbering of applicat ions.............. 48

On and off permits.................... 14

Approval of ......................... 55

Orchard grass ..................... 75

Owners:

of transient stock................... 35

Resident ranch....................... 44

Small nearby......................... 35

Transient, may be grinted permits....... 38

Who purchase winter feed.............. 44

Ownership of ranch property ............. 36

Partuership agreement...

Partnerships, dissolution of...............

Partnerships or corporations, instructions for granting permits..................... 41

(3)

Payments of fees.............

Periods:

Five-year .............................. 19

Five-year must be anthorizediby secretary $\quad 19$

Grazing, method of fixing. . ... 19

Less than one year.................. 9.26

Special........................... 19

Permits.....

Allotments....................... so

Imended, how recorded ............... 48

Amended to be issued ................. 54

Applicutions for ...................... 11

Applications for, date filed ............... 40

Application for, false statement of stoek... 11

Application for, form of............... 89

Application for crossing ................. 58

A verage number of stock to............. 11

$86104^{\circ}-11-7$ 
Permits-Continued.

Cancellation of

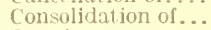

Crossing.

Form of ...

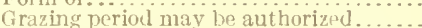

Instructions for making. . . . ............

Must comply with quarantine regulations.

No charge...

Over two forests.

Rangers may accompany stock.

To dipping ints. condit fons governing.

To private lands

To ruach rail road shipping points.

When charae may he made for. . .

Whin denied.

Wlen not reguired:

Denial of

District forest r may recuire copies of .

Deseription of range in

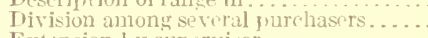

Extension hy supervisor

Extension of

Five-year ptriorl.

For iwo classes of stock uncler protective limit....

Free.

Grizing, form .....

I) olders must comply with live-stock lizws

In excess of protective limit

In triplicate.

Issuecl only after parment.

Issued undir cooperat ive asreement.

Mas be cancelecl......

May le denic d........

May le rofusmel.

Monthly, not prisuicial.

Monthly, only unis exoptional combition

New, to plard

Nonuse of

Not transferalsle.

Nunlbering.

On antl oil.

Fees charceil for

For sheep and goats.

Number to ly. counted drainst allowance. Jrivate land.

IVluen issued.

Will mention full number of animats.

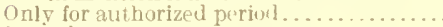

l'roceclure.

lieduetion of ....

Reductions that would tiaro been made

Renewals of .............. $12,11,34,47$

Renewal of for different aliss of socli....

Remewal to corjorat ion..............

Renewals to purchasers.

Speculat ion in use of.

Stock exempt from.

Stock sold under.

Supervisor may withhold.

Supplemental...

Suppiemental, new cart for

Terun

A pjolication for increase.

Ilow recorded....

(n)

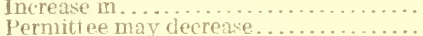

Reduetions ini.

Supervisors need not insist 11 pon.......

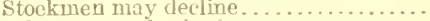

When not authorized.

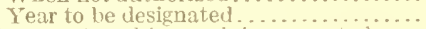

To copartnerships antl incorporateil com panies.

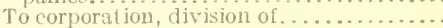

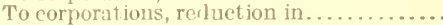

To firms or corjuorations................

To individual, may be changed to partner-

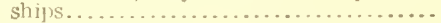

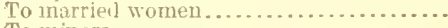

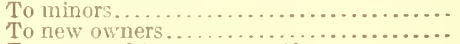

To jartnerships or corporat ions............

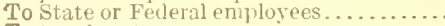

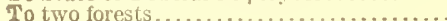

Page. Permits-Continued.

Page.

To unmarried women.................. 37

To whom issued. . . . . . . . . . . . . . . 10

Waiver of ......................... 31

Then new number is giren .............. 54

Will be canceled ..................... 11,5

Will be refused..................... 11

Yearlong, when begin ................. 29

Permittee, change of resirlence of.............

Permitted stock, intrusion upon private lands is

Permittees, who transfer to incorporated com-
pauy...$\ldots \ldots \ldots \ldots \ldots \ldots \ldots \ldots \ldots \ldots \ldots \ldots \ldots \ldots \ldots \ldots$

Plan:

Annual district.

Anmual forest, ....................... 81

Annual grazing ................... 2I

Annual grazing, jorocellure in............ 20

Annual grazing, to be ajplroved by....... 20

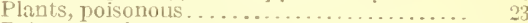

Poisonous plant warning.................

Poison will be furnislled..................... tis

Prairie dogs, extermination of .............

Predatory animals:

Destruction of

Forest officers to hunt

Preferences (sce Grazing).

(b)

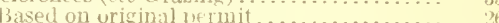

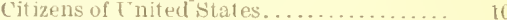

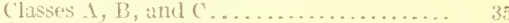

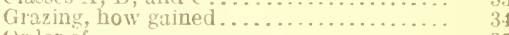

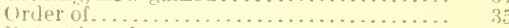

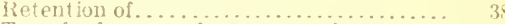

Transfer from one forest to another....... 39

Preserves:

Ciante.

State ganje.

Prior oceupancy.

Private lank

Allowances for.

Grazing capacity

Grazing on Inulian allotinents.......... 5

Instructions concerning use oî............ 5

Maximum linit upon. . . . . . . . . . . . .

Permits to reath ..................... 5

Tnperfected entrics................ 5

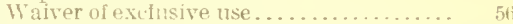

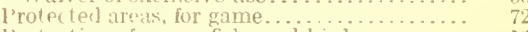

Protection of game, fish, and birils ......... It

General instruct ions................ ti9

Protective limits, hov estahlished .......... 4 .

Purchase of ranches only, procedure in ...... 4.

Purchase of stock and ranches............. 47

Qualificat ions of purehaser..............

Qnalifieat ion of ajplicants.

Quarantine and local laws, general instructions...........................

Quarant ine:

Duty of forest oflicers in . . . . . . . . . 67

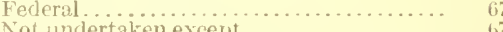

Not undertaken exce

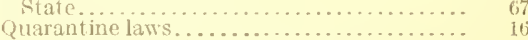

Coopreration with................... 10

Forest service will assist in enforcment... g.

$\checkmark$ iolations of ...................... If

Quarantine regulations, persons must com-

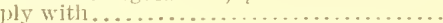

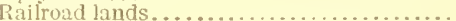

Ranclies:

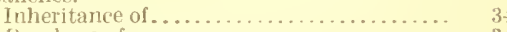

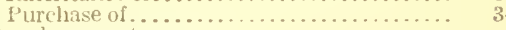

Ranch propert $\mathrm{r}$ :

Conditions governing use of ............ 36

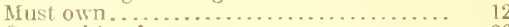

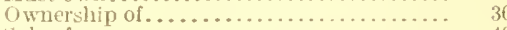

sale of............................... 46

Range:

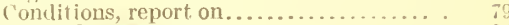

Dependence upon ..................

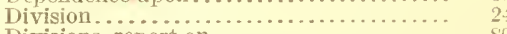

Divisions, report on............... 80

fmprovement, method of.............. $\quad 74$

Improvement, natural reseeding......... 74

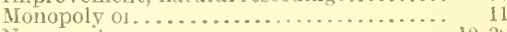

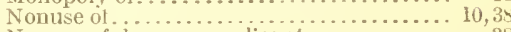

Nonnse of, by new applicant ...............

Prior use of....................... $3 t$ 
Range-Continued.

Regular occujeastey.

Regillar nise of

Reports on condition.

T'emporary use of.

To prevent monopols of

Use of forfeited.

Ranges:

Inclividura]

Stock best adapterl to........

Emised.

II inter.

Rates (ste Fiees)

lbised upon yearlong. .

For periods less than one year.

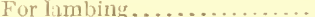

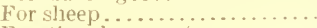

Fructional amounts

Lambing or kidding.

Hinimum

Receipts, srezing, check upon...

Reconmendations, in ammual forest plinn...

Records:

Confirential

Eximination of m...

Reductions:

Inntal. .................

In numbers, how maile.

In term permits.

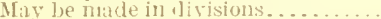

When stock and ranches are purclinseid.

Rethon,

Refinges:

Bircl, anthority over.

Giame and biril.

Game, authority of forest oflicers.....

Game, national, jurpose of...

Grame Stiate.

Refunds.

Account of sale of stock................

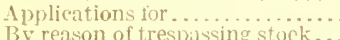

Disunproval of

District forester will ilecide....

Error by forest onlicer...................

Grounds fot.

Not to exceed...

Procedure for securing .

Reasons fior refusing

Renewals for so per cent

To he noted on carl recoril.

Regulations are supreme.

Renewal:

Of permits .....................

Reduction in numbers.

IThen stock and ranches are purchised...

Reports:

Ammial.

Distrivi plian.

firazing section of. .

Statistical, when made

Comting, rangers to supervisors.

District foresters.

Forests statistical...........

Ilunters. . . . .

On grazing cuparity of prirate lam .....

On stack and ringe, quarterly.

12uarterts....

(2uarterfy, rangers.........

simpervisor's annmal forest ptan.

sumervisor's amnual statistical. . .

Respecting:

Irtificial

Vitural.....

()perations-

Choice of arens.

Reports nipon.

Samples of form

Spring $"$ filtl seetling .

Residence, enditions governim

Rewards, may not accept ......

Ronds and trails:

Damage by stock.

1'rotection of

Roads, damage to.
Page. liound-up:

I'ilge.

Forest olficers to accompany . . . . . . ti.

Instructions concerning........... dif

Forest officers mity tasist ............

Rumning stock on siares..........

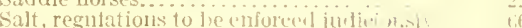

Salt-grounds, lociation of............. is

Salting stock.......................

fienerul instructions.................. fit

When owner refuses.......... the

Seasons, grazing (sec Period) .... It

settlement of coatroversies........ If

Procerlure for.................... in

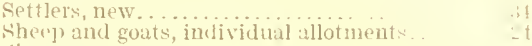

Sheep:

Charges for dry

Exisss over fremit.

Grazing of, not alfower] intil

Improved methorls of handlin:

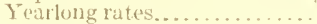

slirling seale.

Instructions for use of . ..............

Reductions...

speculation:

In use

Preventin

Damage to.

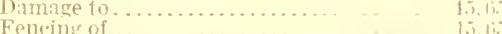

Shere and goats not bedded bear ........ 15

Squatters:

Upon unsurvered lands...

Cliairis

State employers, permits te...

State selections.

Stoek:

Amonnt of salt required

And ranches, when lootis are purchia ond.

Applicant mar purehase.

Applicants who own dillerent edases

Bought by several jurehaser:

Capture or removal of, cxpenses for.

Contition of .

Counting, applicant who refuses.

Counting of

Damage by

Tearl, disposition of....

Detectives..

District forester fo letermine kini.

Division of.

T)irision of ontfits.

Driving ar ross national foresty

Emergency concessions.

Exelusion of.

Exelnsion of, for silvicuftural reatsons

Exelusion of, when alvisalble.

Exompt from permit.

Exempt from Jermit, discretion of supervisors. . .

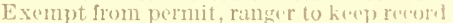
of.

firazeil free. report on

Grazing on protected areas.

Grazing without permit.

In excess of protective limit

Increased number not alloweri

Inheritance of.

Intrusion on private lands...

killed by aceilent, diseasm, poisonomis

j) Jnts, or wild animinls. .

Kinil not previously allowit.

leasing of .

May be exiludeil from.

May be replaced.

May be reptaeed if solit or rinovert

May enter in advanee.

May remain 15 dars after.

Aeeting, forest officers atteruling.

iIfere purchase of.

IIortality r'inrt.

Mort gaire on.

Mortgagecl, renewaj of permit.

Natural increase of .............. 
Page.

Stock-Continued.

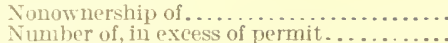

Number of, in excess of permit...........

On open ranse.

Permiltee ehanging class of

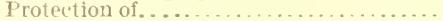

Purchase of.

Purchase to fill range.

Purchaser of.

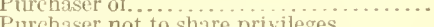

Range estimate of numbers.

Ringers assist owners to protect.

Rates for, periods shorter than yearlong.

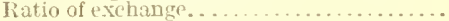

Ruming ou shares.

Sold anil removed.

Sold and slaughtered.

Strav, duties of owners.

stray or unbranded, instructions for handling.

Stray or unbranded, forest officers not to

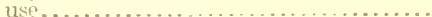

Supervisor may exclude... . . . . . . . . . . . . .

Theft of.

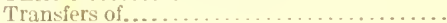

Transient

.

Welfare of.

When in trespass.

Stray or unbranded stock, instructions for...
39

63

41

46
80

34

31
32

32
12

47

16

16
64

64
67
Supervisor may deny permit.

Supplemtental, form to be marked............

Swine, yearlong rates.................. g

Term permits:

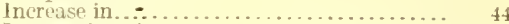

Instructions for . . .

Renewal of ............................ 4

Three per cent of allotiment to beginners..... 43, 4.

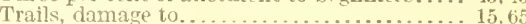

Transient owners, permit to.............. 38

Traps will be furnished................. tis

Trespass:

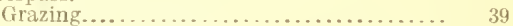

On protected areas for game................... 72

Twenty per eent reduetion for new beginners. 45

$\begin{array}{ll}\text { Unbranded stock, instruetions for hancling.. } & 73 \\ \text { Unsurveyed land, squatters upon........... } & 57\end{array}$

Waiver:

Of grazing preferences................ 12

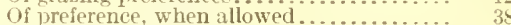

of grazing privilege, form of .............. 91

Of preference, conditions in use of......... 38

Warlens:

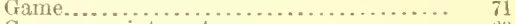

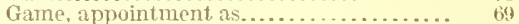

State game......................... 70,72

Water:

May be piped......................... 15

Rights, when considered...............................

Watering troughs, open for public use...... 15

Widow, permits to ..................... 37

Winter ranges......................... 19

Woman, unmarried.................... 37

$\begin{array}{ll}\text { Work animals ................................ } & 22 \\ \text { Yearlong permits, when begun and ended... } & 2 y\end{array}$ 





LIBRARY OF CONGRESS 